\title{
ARS MORIENDI AS SOCIAL REALITY: \\ ARTICULATION OF THE GOOD DEATH IN THE UNITED STATES
}

A Dissertation
presented to
the Faculty of the Graduate School
at the University of Missouri-Columbia
In Partial Fulfillment
of the Requirements for the Degree
Doctor of Philosophy
Dr. Srirupa Prasad, Dissertation Supervisor
DOUG 2021


The undersigned, appointed by the dean of the Graduate School, and examined the dissertation entitled

ARS MORIENDI AS SOCIAL REALITY: ARTICULATION OF THE GOOD DEATH IN THE UNITED STATES

presented by Douglas Valentine, a candidate for the degree of Doctor of Philosophy, and hereby certify that, in their opinion it is worthy of acceptance.

Professor Srirupa Prasad

Professor Joan Hermsen

Professor Rebecca Scott

Professor Dennis Kelley 


\section{ACKNOWLEDGEMENTS}

This dissertation is the culmination of a much more holistic experience of graduate education at the University of Missouri over the past seven years. As such, I find it entirely appropriate to acknowledge the numerous faculty, staff, graduate colleagues, undergraduate students, and family who made an impact and provided support during my academic and professional pursuits. First, I would like to acknowledge the support of my wife, Chandra, and sons, Hollis and Simon. Chandra was seven months pregnant with our first son when I began my $\mathrm{PhD}$ program. Balancing family obligations with the pressures of graduate education and timelines is one of the most significant, unspoken challenges of many graduate students. Their support has kept me going even when times were tough. I would also like to acknowledge my parents, Stan and Sandy Valentine, who have remained steadfast in their support of what no doubt seemed like a never-ending college student career. My identity as a first-generation college student played a significant role in shaping my academic pursuits throughout undergraduate and graduate school.

I would also like to acknowledge my faculty support: my dissertation advisor, Srirupa Prasad, and my internal committee members, Joan Hermsen and Becky Scott. During a time of intense departmental upheaval, I was fortunate enough to keep my committee intact for the duration of my studies, which may not be something many others can say. I would also like to thank my outside committee member, Dennis Kelley of Religious Studies. Dennis served as my MA thesis advisor from 2010-2012, which was also formative in my decision to continue graduate education. I would also like to thank the numerous faculty who pushed me to think critically across multiple colleges, 
departments, and disciplines: Amit Prasad, Tola Pierce, Victoria Johnson, Clarence Lo, Wayne Brekhus, Chip Callahan, Ed Drott, Jeni Hart, Enid Schatz, Rebecca Dingo, Marjorie Dorime-Williams, Amalia Dache, and Brad Curs.

Many graduate school colleagues have greatly influenced my time in the Department of Sociology. I would like to acknowledge my graduate cohort: Brittany Presson, Jeff Stilley, and Isais Wellington Smith. Many other colleagues in the Department of Sociology were equally valued for their guidance, influence, and insights: David Criger, Julien Gayer, Kristen Kalz, Matt Knudtson, Aaron Padgett, Don Willis, Justin Yates, and others. I would also like to acknowledge some of the undergraduate students who have pushed me to be a better teacher-scholar as a graduate instructor: Abuzar Bhatty, Kristen Biondo, Jessica Blake, Juliana Cole, Jack Graham, Mollie Harrison, Ashtyn Howard, Izzy Janney, Brooke Kenney, Eleanor McCrary, Megan McLeod, Daniella Reyes, Bradford Siwak, Becca Wells, Jake Young, and numerous others. 
TABLE OF CONTENTS

ACKNOWLEDGEMENTS ................................................. ii

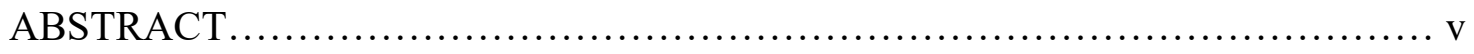

Chapter

1. INTRODUCING ARS MORIENDI AS A SOCIOLOGICAL CONCEPT...... 1

2. "THEY KNOW WHAT THEY WANT" NATURAL BURIAL AND THE CONSTRUCTION OF THE IDEAL CLIENT............................ 25

3. FIRE TO WATER, ASHES TO ASHES: A COMPARATIVE ANALYSIS OF FIRE CREMATION AND ALKALINE HYDROLYSIS IN U.S.

DEATHRITES................................................ 43

4. DYING RESPONSIBLY: THE GOOD DEATH AS NEOLIBERAL INDIVIDUATION ................................................. 62

5. CONCLUSION: DEATH \& DYING IN A POST-PANDEMIC WORLD..... 85

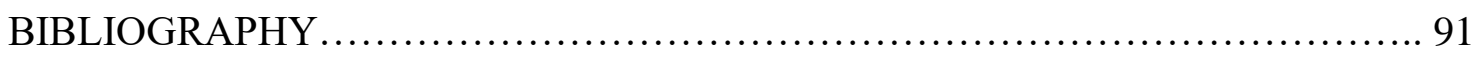

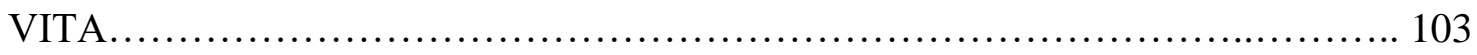




\title{
ARS MORIENDI AS SOCIAL REALITY: ARTICULATION OF THE GOOD DEATH IN THE UNITED STATES
}

\author{
Douglas Valentine
}

Dr. Srirupa Prasad, Dissertation Supervisor

\begin{abstract}
Death and dying are often theorized as micro-level processes, focusing on the experience of the death process from the perspective of the dying, or in the context of grief and psychological healing on the part of the bereaved. While these academic analyses have merit, their analytic utility is limited. Death, dying, bereavement, and memorial are social processes that require multidisciplinary investigation. Utilizing sociological, religious studies, and ritual studies methodologies, this dissertation explores ars moriendi, or the good death, as a process enmeshed within the macro-structural forces of political, religious, economic, and social institutions. Through these discrete case studies, the dying and the bereaved are recentered as active agents driving and responding to change within the contemporary American death industry.
\end{abstract}




\section{Ch 1. Introducing Ars Moriendi as a Sociological Concept}

\section{Introduction}

I recognized inequality in deathcare from an early age. In fact, the American cemetery is one of the first places I engaged in sociological thought. As a fourteen-yearold gravedigger, I recall studying the various services and material goods used during burial, and how these services and goods varied widely among the deceased and their bereaved. For some, services were simple: a quick graveside viewing, after which family and friends meandered through the methodic aisles of cemetery plots and headstones, eventually leaving cemetery staff to do their work. Caskets and vaults were often equally modest, the latter sometimes little more than a hallowed block of rectangular concrete. Others were not so modest. Releasing a dole of doves or hiring ceremonial bagpipers signaled affluence or its approximation. Stale, gray concrete was upgraded to engraved marble vaults housing solid oak coffins. I remember witnessing these differences, noting them, and trying as a teenager to understand how there could be such variability between individuals and families for such a universal phenomenon: death.

Despite several topical - and a few disciplinary - shifts in research, death and dying have remained a central focus of my academic pursuits. The last two decades of my life have operated, in some capacity, in the academic and professional realms of death and dying. Death is an important topic within sociology for two reasons. Most importantly, we will all experience death. First as mourners, then as the mourned. Few social processes affect every person so thoroughly and directly, yet the sociology of death and dying remains a small, niche subfield within the discipline, more broadly. Second, one of the 
major goals of sociology is to challenge common sense, and other decidedly unsociological views of the world. How Americans view death is no different. Shining a light on the ways social inequalities remain operative during and after death challenges the assumption that death is "the great equalizer" in the contemporary United States, a challenge already taken up by the sociologist Deborah Carr (2016) and others.

These scholars have challenged the rhetoric of death as equalizer through the concept of the good death, or ars moriendi. Most of this literature articulates the good death as linked to process of dying. Put another way, the good death exists for the dying individual, combining concerns for existential peace and painless cessation (Hart et al 1998; Carr 2016). Ars moriendi itself, a concept rooted in the late Middle Ages, translates to "the art of dying" or "dying well," suggesting an individual attention to the process of cessation (Gilpin Faust 2009). I conceptualize good death differently. In addition to individual peace and painlessness at the time of death, achievement of ars moriendi in the United States encapsulates a range of temporal processes before, during, and after the biological cessation of a decedent. Aspirations for ars moriendi begin in the early stages of deathcare planning, extending post-death through rites, rituals, and memorializations aimed at honoring the dead and reminding friends and family of their shared bonds.

Ars moriendi is a social phenomenon, incorporating multiple actors across various stages of the death, grief, and memorial processes. While preplanned memorial services and individualized funeral arrangements center the individual as a conscientious consumer of deathcare products, untimely or unplanned death requires friends and family to approximate the wishes of the deceased, drawing on established cultural norms and funeral industry standards (Seale 1998; Kastenbaum \& Moreman 2018). How cultural standards 
are maintained and changed, as well as the amount of influence industry experts have in effecting these cultural expectations is hotly contested in the literature on death and dying (Beard \& Burger 2017). What the good death means and how it is achieved depends on the institutional context in which the dying and their survivors find themselves. It is important to remember that good death is not a monolith. Its articulation is mediated by social structure and acted upon by the dying, the bereaved, and industry professionals, as well as religious and governmental authorities.

Ars moriendi as a social phenomenon is vital to a well-rounded understanding of how social inequalities play out in the context of death and dying in the United States. The achievability of ars moriendi often hinges on the ability of individuals, family, and friends to procure the goods and services necessary to ensure that final wishes are carried out in culturally sanctioned ways. Often, ars moriendi requires financial capital through savings, life insurance, or community resources. As a social process with numerous actors, a failure to achieve ars moriendi has far reaching effects beyond the dying themselves. The inability to achieve the good death for friends or family stands as a direct challenge to religiocultural scripts informing a commitment beyond the grave.

This collection of essays highlights three socially mediated articulations of the good death in the contemporary United States through three discrete research articles. First, the popularity of natural, or green, options is explored through interview data with roughly two dozen green burial practitioners. Stressing motivations of fiscal responsibility, ecoconsciousness, and the re-centering of the family in deathrites, green burial practitioners play a co-constitutive role in shaping the ideal green deathcare consumer. Second, contemporary arguments for and against the legalization and ethics of alkaline hydrolysis, 
also known as resomation or liquid cremation, are contrasted with nineteenth and twentieth century anxiety surrounding the development of industrialized fire cremation, illustrating the complex web of political, economic, and religious actors framing the social scripts of ars moriendi today. Finally, the growing industry of advanced-planning memorial services is analyzed as a rearticulation of ars moriendi as the personal responsibility of future decedents well in advance of illness, aging, or untimely death. These unique explorations are brought together by a set of research questions. First, why is each of these articulations so important to the broader concern for the good death? In what ways do these cases show the social, rather than isolated, reality of death and dying? Second, what structural forces drive each of these articulations and what do individuals, families, and friends do to navigate the achievement of ars moriendi? Finally, and deceptively less simple, why is the achievement of ars moriendi so important?

\section{Death Inequalities, Deathrites, and Death as a Social Phenomenon}

A growing body of literature has challenged the understanding of death as "the great equalizer" (Moodie 1998). Carr (2003) argues the good death must be met across several conditions. These include a) the physical comfort of the dying individual, b) the availability of proper social supports for the dying, c) the decedent's ability to accept the inevitability of death, and d) that appropriate medical care is available to the decedent prior to death. Each of these conditions may be met with varying levels of success or failure. Most notably, significant relationships have been established between socio-economic status and two variables of the good death: pain and advanced care planning (Caralis et al 1993; Carr 2003; Carr 2016). 
Elsewhere, advanced care planning has been linked to net worth, controlling for demographics, health, and psychological variables (Carr 2012). This included individuals' likelihood of creating living wills with few financial assets, as well as individuals' tendency to convey their personal wishes for end of life care, both of which partially contribute to poorer care. The relationship of end of life care to wealth also indicated that wealth is tied to knowledge of end of life options, more generally. Individuals of lower SES simply knew less about their choices for care, making them less likely to designate specific wishes and practices (Carr 2012). Lewis et al (2011) found similar results through archival research using several palliative care databases. They concluded that many of the life experiences associated with low SES negatively affect health literacy and an individual's ability to access medical interventions prior to end-of-life catastrophe. This research extends the discussion of inequalities in deathcare planning through an investigation of deathpreparedness web companies, described below. Who accesses these resources, and to whom these resources are marketed through rhetorics of personal responsibility and individuation, both reflect and reproduce these disparities.

Quality deathcare outcomes have also been linked to racial inequity. Assumptions of Black pain tolerance, informed by decades of institutionally-legitimated biological racism, is one explanation for racial inequity across one metric (Washington 2008). Carr (2012) found that both Latinx and Asian groups were less likely to discuss deathcare options openly with family or friends, though Asians were more likely than whites to have a living will. In addition, differences between Black and white populations were only significant when combined with low SES. In fact, when individuals own a home, Blacks were significantly more likely than whites to discuss end of life plans. A lack of home 
ownership among racial groups showed a higher likelihood for whites to discuss death preparation than other racial groups. Likelihood of discussing end of life planning is also influenced by religio-cultural contexts (Carr 2011). Among lower income Blacks, lack of deathcare planning correlated with a stronger belief that God determines the time and cause of death. Differences between Latinx and white subjects also correlated to the former's belief that illness and death negatively affect the family, resulting in a desire to avoid discomforting conversations.

Many American medical practitioners, gerontology, and palliative care scholars subscribe to the criteria outlined above. However, a small but growing number of medical scholars highlight the absolutizing and ethnocentric assumptions of the qualifiers necessary for achievement of the good death, leading them to question the overall utility of the concept. Pollock and Seymour (2018) suggest that "[ $t]$ he 'good death' is a largely professional and ethnocentric construct, which takes no account of cultural diversity and the different values which may be espoused by different groups or individuals, for example regarding continuation of 'futile' treatment, or the use of pain relief." Others highlight the discriminatory nature of linking the good death with the ability to plan timely deaths and procure pain medications or palliative care, leading to the development of a dying underclass, including lower- and working-class communities, rural Americans, and people of color, for whom ars moriendi is structurally inaccessible (Lowerie et al 2018). Others have called for a more thoughtful social class analysis in the construction of good death criteria (Howarth 2005).

Academic and journalistic explorations of the deathcare industry are generally divided into two camps (Beard \& Burger 2017). The first, illustrated by Mitford's (1963) 
exposé of the funeral industry, takes a critical approach to deathcare products, norms, and innovations. Business-related motivation refers to those decisions within the deathcare market, both by individual deathcare professionals and the industry at-large, driven solely or significantly by business goals. In this perspective, the bereaved are helpless victims of a professionalized expert system, generally engaged in unethical behavior, and are easily manipulated by salespeople masquerading as grief counselors. Grieving families' ability to take ownership of deathrites is severely hindered by their lack of industry knowledge and the time constraints of preparing the body.

The second camp of scholarly investigations focuses on the desires of consumers driving and sustaining modern industry standards. According to Laderman (2003), industry professionals play a vital role in mediating the interpretive and ritual frameworks of modern deathrites, but this mediation is not solely, or even primarily, profit driven. Rather, the bereaved operate within a constellation of "emotional, psychological, religious, and cultural dimensions of disposal" through which the American way of death is reproduced and adapted ( $\mathrm{p} x \mathrm{i}$ ). These essays chart a middle ground, considering the emotional and psychological motivations of the bereaved, how those motivations are informed by religiocultural scripts. At the same time, profit-motivations within an adaptable industry cannot be ignored.

Family and friends are not passive objects of inaccessible social institutions and regulation. Rather, the religio-cultural scripts of death, dying, and bereavement shift relationally across time. Walter's (1994) topology describes macro-level shifts in the functioning and makeup of death and bereavement. His three archetypal forms of death traditional, modern, and neo-modern (elsewhere called postmodern death) - are each 
characterized by changes to the bodily context, social context, and authority surrounding death, though these changes do not always occur simultaneously. These ideal types represent shifts in coping strategies of the bereaved, as well as the values assigned to the death and memorial process. In his analysis, death rites around the world through most of human history fall under the rubric of traditional death, in which local communities inform the social context of dying, which is frequent and typically unexpected or quick. Family and friends are centered through personal care for the decedent and preparation of funerary rituals with the aid of religious authority. Lower median ages of death result in a reverence for elders and their veneration upon expiration. Perhaps most importantly, death and bereavement as communal acts place a greater (in some cases total) emphasis on public acts of mourning. Funerals and cremations function as a ritual equally for the dead and the living, reaffirming communal bonds and lineage.

Conversely, modern death is characterized by privatization. Rituals and responsibilities that were previously held by family and friends are now subject to expert systems, including a workforce specializing in various aspects of deathcare. Virtually every aspect of post-death preparation is handled by these experts, with death increasingly sequestered to hospitals shielding the public from view. From the time of expiration to internment, the body migrates between a litany of specialists, including morticians, embalmers, Hearse drivers, and grave diggers. The process of death and funeral preparation has left the realm of religious authority, relaying almost exclusively on medical and funeral industry expertise. The body becomes an object, not of religious consideration, but of medical intercession. The corpse now carries the potential for pollution, making it dangerous, not in a supernatural sense, but a medically contagious one. 
Grief and bereavement in modern death are also largely private affairs, only occurring publicly at sanctioned times and in specific contexts. Outward displays of grief are afforded less and less time and space, as month or even yearlong memorial rituals give way to incredibly conservative bereavement policies held by many American corporations. Short allowances for leave, as well as the precarious employment statuses of hourly or contingent labor, often makes travel to funeral services or subsequent remembrance gathering impossible (Cann 2014). In this arrangement, grief should be private and of short duration. Emphasis is placed on "getting back to normal" and grief is viewed as something to "overcome."

The pressures to hide or ignore public grief and mourning echoes Giddens' (1991) explanation of the sequestration of experience in modernity. According to Giddens, modernity is a self-reflexive project characterized by the replacement of externally referential social structures for similar internal referents. The process of rejecting externality includes a de-emphasis on place through disembedding mechanisms. Whereas funerary and memorial practices had previously centered on a fixed ancestral hall, family mausoleum, or community cemetery plot (i.e. traditional death), younger generations increasingly find themselves removed from familial localities and placed in large, urban metropolises devoid of structural resources to support filial obligations to the dead.

Prior to the modern shift, sickness and death were largely public matters regulated through communal ritual. It is not until the hospital, forerunner to the modern prison and asylum, separated itself from organizations designed to combat "the poor problem" that ailment became increasingly hidden from public view. The common practice of dying in one's home, surrounded by family and friends was replaced by solitary deterioration in the 
sterile confines of the modern medical center. As illness, death, and dying receded from public view, the ability to cope with and accept death similarly deteriorated. Mellor and Shilling (1993) point to several factors expediting the privatization of death in high modernity, including the re-ordering of biographical narratives in the construction of selfidentity, increased identification of self with body, and a decreasing availability of religious meanings and ritual structures. The contemporary prevalence of a neoliberal discourse on consumption, individuation, and responsibility further shifts this authority. However, I problematize Mellor and Schilling's absence of religious meanings and ritual structures. Contemporary deathrites have their own interpretive and ritual frameworks informed by multiple subjectivities and institutional influences.

\section{Religious Studies, Ritual Studies, and Sociology in the Analysis of Ars Moriendi}

I have characterized my time in academia as an interdisciplinary pursuit, drawing from backgrounds in religious studies and sociology. It seems fitting then, that the entry point for ritual analysis of death and dying be a central figure in the development of both disciplines. In The Elementary Forms of Religious Life, Durkheim (2001) sought to designate those essential elements present in contemporary religious systems. Though the methodological assumptions guiding his study are problematic, his theoretical insights regarding the function of religion in pre-modern societies still have analytic utility. According to Durkheim, religion serves two key roles. First, as a classification system for the sacred (powerful, forbidden, oriented to the community) and the profane (mundane, practical, oriented to the individual). Second, religion binds a community together through collective rites. During these rites, community members reinforce their commitment to the unit, often experiencing what he called collective effervescence. Pals describes this process: 
In these great and unforgettable ceremonies, worshippers seal their commitment to the clan. In their moments of great excitement, in the wild emotional ecstasies of chanting and dancing, individuals acquire sentiments and undertake actions they would never be capable of embracing on their own. They leave behind what is most distinctively their own and merge their identities joyfully into the common single self of the clan (Pals 2006, 101).

In addition to these joyful expressions of solidarity, Durkheim described what he called piacular rites. Chief among these were rituals of atonement and mourning following a death. Much like his earlier analyses of suicide, Durkheim challenges the popular notion that emotive reactions to death are spontaneous and random. Rather, these practices are "strictly governed by etiquette ... They lament, not simply because they are sad, but because they are obliged to lament" (Durkheim 2001, 291-295). Just as rhythmic chanting or dancing reaffirm group unity during socially prescribed ritual acts, so too do proper responses to death (eg. wailing, tearing one's clothes, beating one's chest) express commitment to the community. Here Durkheim turns the unidirectional relationship of belief leading to practice characteristic of Marx and Freud, on its head. In the case of ritual mourning, fear of malevolent spirits did not necessitate rituals of atonement and mourning. Rather, rituals of atonement and mourning were legitimated by subsequent conceptualizations of malevolent spirits and obeisance, which becomes "not the source of mourning, but its consequence" (Durkheim 2001, 298). Here, Durkheim provides some of the earliest suggestions of practice preceding belief among Western scholars of religion. Still, Durkheim's functionalist approach - that norms, beliefs, values, and practices exist and are maintained due to their essential utility - only takes us so far. Were it the case that 
ritual, and in this case piacular ritual, only served to remind community members of their commitment to the whole, we should see very little complexity in these and similar rites across societies. By reducing religious activity to their essential functions through deduction, functionalist theory ignores the diversity of ritual across space and time.

Many contemporary scholars have contributed to practice-oriented analyses of religion and ritual that inform discussions of death and dying. Smith (1982) highlights the processes by which seemingly banal and profane occurrences have a tendency to routinization on the road to becoming essential features of ritual practice. As with efficacious spirits responding to successful or unsuccessful death rites, routinization of random occurrences (eg. leopards drinking from ceremonial dishes or caravan travelers receiving water from a ritual priestess), the legitimation of inclusion comes after the inclusion itself. Additionally, the messiness of practices in-the-world led Smith to theorize ritual outside of material efficacy, i.e. complete ritual X for desired outcome Y. Rather, the primary goal of ritual is the negotiation of incongruity between how things ought to be and how things are. To illustrate his point, Smith explains hunting rituals among paleo-Siberian communities. Smith points out many hunters, prior to beginning the hunt proper, will act out a ceremonial hunt or offer lamentations for killing the desired animal. Every action is carefully prescribed, including the language used, which the animal is presumed to understand. For example, many times the animal must present itself freely, must be asked for forgiveness by the hunters prior to being killed, and must be killed without the messy loss of blood. In reality, however, these prescriptions cannot be adhered to. A bear will never give itself up freely, will never wait patiently for an apology or declaration of intent, and the slaughter is often very bloody and violent. To reconcile how things ought to be 
with how they are, ritual practitioners cannot truly believe their proscribed actions effect a desired outcome. Rather, according to Smith, ritual acknowledges the ideal procedure of a given situation while, at the same time, reconciling that ideal to the way things happen in reality. Other ritual scholars refer to this enactment of ritual as creating a subjunctive reality - "an 'as if' or 'could be' universe" (Seligman et al. 2008, 7).

Using Smith's theory of ritual negotiating incongruity may be a fruitful heuristic to understanding the desire among grieving family to achieve ars moriendi, especially in cases of untimely death. How do survivors conceptualize what death ought to be? The drive to procure acceptable death rites may be an attempt to reconcile this ideal with the reality. When negative religious, governmental, and industry mediations deny this negotiation through meaningful ritual, how is this tension remedied and what does this tension do to families' and communities' view of their relationship to ars moriendi? Smith also describes the tendency for routinization of the previously profane and banal in the process of ritualization. Routinization of practices driven by the political economy of the contemporary American death industry may also help explain how relatively young death rites become essential to achieving the good death (eg. 'packages' sold by death industry professionals, the assumed centrality of embalming for 'traditional' American funerals).

Studies of the ritual process must also consider death and its communal responses as rites of passage. Here, the work of van Gennep, Turner, and Grimes are particularly helpful. As Grimes (1995) says, though contemporary North America is "ritually impoverished," birth, coming of age, marriage, and death constitute a conventional scenario, or schematized plot of how life ought to progress. Van Gennep (1960) described rituals as magico-religious ceremonies that were, using materialist language, embedded in 
the world. This worldly-embeddedness informed his focus on processes and passages in human life, which became a central concern of Turner's work.

Turner's contribution to ritual studies includes two concepts that are essential to analyzing contemporary death rites and the desire of close relations to provide the good death: liminality and communitas. "Liminal entities are neither here nor there; they are betwixt and between the positions assigned and arrayed by law, custom, convention, and ceremonial ... [L]iminality is frequently likened to death, to being in the womb, to invisibility, to darkness... (Turner, 1969, 95).” Given medical advances and care taken in preparation for death, scholars began using the term death and dying to designate the process of dying and that this process encapsulates far more than the moment of expiration, just as the term deathrites points to more than simply a funeral or burial, but the numerous components that go into achieving the good death. As such, how might liminality describe the in-betweeness of life and expiration? Shifting focus from decedent to grieving survivors, the process of mourning and memorializing may constitute a liminal pre/post lose state of being, as folks may not feel the full weight of lose until the final death rite has been completed, whether it be burial, the scattering of ashes, or when the door closes after the final well-wisher offers condolences. Mourners, comprised of friends and family of the deceased, also exhibit a flattening of rank and social status, as grief and lose does not discriminate.

Hierarchy and rank are flattened through Turner's concept of communitas which designates the fleeting, liminal "moment in and out of time," made of up undifferentiated comitatus, or a community of equal individuals under the guidance of ritual leaders (Turner 1969, 96). Unstructured communitas exists in a dialectic process with social structures 
through the cycles of rites of passage. As such, one's personal death may be viewed as a final rite of passage, while the experience of death and lose helps define the cyclical process of life in a community. Though each member of a community only dies once, death within the community becomes routinized, drawing again on Smith's understanding of the term in relation to ritual, creating a liminal space to reaffirm group commitment and comradeship on a horizontal status field.

Ritual can manifest, through the body, positions within a social hierarchy. This means much is at stake through ritual. For Grimes, ritual consists primarily of two parts: cultivation and negotiation. To establish meaning in otherwise random acts, rites "facilitate or obstruct difficult passages in the course of a human life ... We undergo passages, but we enact rites" (Grimes 2000, 5). We fight with, over, and for ritual. Ritual is "a political act requiring the exercise of judgement and use of power" and "a right fought over (Grimes 1995, 5)." Ritual, in this sense, may be a site of both resistance and submission. According to Rappaport (1999), ritual movement not only signifies a particular social position, but also relationally creates those social positions. Through the act of kneeling, the subordinate not only signals "I submit," but constructs the physical submission itself. The subordinate is created through the ritual act. This relates to Foucault's (1980) notion that technologies of the body are reinforced through routinized ritual practice, replacing previous methods including public execution and torture with what he called asepsis of the social body: sequestering undesirables, eugenics, etc. Bell (1992) extends this theory through her concept of the ritualized body. The ritualized body is the product of ritualization, which Bell views as a unique form of socialization, often in relation to power, but also within structured and structuring environments discussed by Bourdieu. Ritualizing forms of 
socialization within structured and structuring environments leads to a misrecognition of those practices and prescriptions originating from an other-worldly source. This process of ritualization creates schemes, or what Grimes calls scenarios, to supersede other social contexts.

There are a few ways to apply these theories of the body in ritual to my examination of contemporary death rites. First, how does the scheme of the ritualized body through socially sanctioned death rites experience tension when confronted with untimely death or a market that is exposed for nefarious sales practices? As with Smith's bear hunt, survivors seek order and controllability in response to an uncontrollable event. The ability to carry out proper, controllable rites for the decedent could be viewed as an attempt to mitigate the uncontrollable, seemingly chaotic events from which death resulted, or the desire to transcend socioeconomic limitations in procuring adequate deathrites. The good death as ritual constitutes an exercise in power and resistance. That there are multiple articulations of and means of financing the good death illustrate Grimes' cultivation of ritual for the purposes of addressing incongruity. Put another way, survivors strive to achieve the good death through rites for those who experienced a bad death.

In "modern death," dead bodies are viewed as alien contaminants which need to be removed. Moreover, only professionally trained individuals are qualified to move them. Through these developments, corpses become hidden from view, foreign, dangerous, and are more easily seen as pollutants. They become what Douglas called "matter out of place" (Douglas 1978, 35). Matter out of place can be explained as something seen as particularly polluting in a context outside of its typical setting. For instance, a work boot is not necessarily polluting on its own. However, if that work boot is placed in the middle of a 
dining room table, it becomes polluting as it is occupying space it has no business occupying. For Douglas, concerns with pollution are analogous to a maintenance of the social order. Having been influenced by increased medicalization of death and the privatized death rite industry, dead bodies are commonly understood to have no business in any environment occupied by the living. As contaminated objects handled only by trained professionals, any place is viewed as out of place for a corpse, except for a grave plot or urn, both of which function to conceal the deceased rather than draw attention to them. The current acceptable classification of dead bodies should be matter out of sight. As I will show, the contemporary green burial movement directly challenges this theorization of pollution, while historical and current arguments surrounding fire and liquid cremation draw centrally upon it.

This feeling of "matter out of place" can be similarly connected to those who deal with death through what Frazer called the law of contagion. According to Frazer, "things that have once been in contact with each other continue to act on each other at a distance after the physical contact has been severed (Frazer 2009, 11)." Given the taboos associated with handling the corpse in the contemporary West, it makes sense that survivors would wish to procure as much financial aid as possible to give their deceased friend or relative the good death. Irrespective federal, state, or local policies regarding the disposal of human remains, the medicalization of death has resulted in the desire to keep the treatment of dead bodies in the hands of professionals and away from public view. Put another way, survivors want to provide their friends and relatives the good death, but they are often disinclined to conduct those essential functions themselves. 
The semiotic analysis of death and the body is also essential to this collection of essays. Central to any symbol system are signs, comprised of both a signifier and a signified. A signifier, typically an object, vocal, or non-vocal gesture, must point to something beyond itself, or to that which is signified. A corpse may signify any number of things: war, devastation, contamination, risk, sacrifice, lose. It may signify finality, as is the case in many Western Christian contexts. In other settings, the corpse may convey the continuation of a reciprocal relationship of living to the ancestors. The process of death, including death rites that extend beyond the expiration of the deceased individual, also signifies. Bodies may even signify in their absence. Laderman (1996) highlighted the deaths of George Washington and Abraham Lincoln as illustrative of evolving attitudes toward death in the nineteenth century. Washington's death in January of 1800 was marked by mock funeral processions around the country. Though Washington died and was entombed at his home in Mount Vernon, his absent-body signified national unity and mourning through symbolic reproductions of his funeral ceremony in places like New London, Connecticut, New York City, and Philadelphia. Abraham Lincoln's death sixtyfive years later, on the other hand, highlighted the development of a far greater emphasis on the symbolic importance of the physical body following the advent of embalming processes, culminating in a multi-city viewing tour from Washington D.C. to entombment in Springfield, Illinois. In both cases, the mourning of a national hero signified unity and social solidarity, but the sign of these significations, the absent-body of Washington through ceremonial reenactments and the embalmed present-body of Lincoln on a prolonged migration back to his place of birth, changed considerably. 
Totemic artifacts point beyond themselves according to socially agreed upon meaning. As such, the bonds between sign and signifier are largely arbitrary (Long 1986). However, symbol systems and signification does not happen in cultural isolation. The West has a long history of signifying "from the center" out to our objects of study. Long's critique of Western scholarship and its intimacy with the colonial project reflects a central hinderance of contemporary death and dying scholarship. For example, though Walter's typology offers interesting vantage points for the study of death rites and memorial, particularly in the case of neo- or postmodern death, his distinction between premodern and modern death is far more problematic. In reading Walter's archetypal forms of death rites, it is important to consider Long's claim that:

The self-conscious realization of the Western European rise to the level of civilization must be seen simultaneously in its relationship to the discovery of the new world which must necessarily be perceived as inhabited by savages and primitives who constitute the lowest rung on the ladder of cultural reality (Long 1986, 84).

Premodern death rituals and dispositions have been signified from the center, as Long says. Just as the methodological assumptions guiding Durkheim's earlier study of the elementary forms of religion assume a linear progression of civilization, so too does Walter's typology of death.

Finally, contemporary studies of death and dying must address death and memorial in the context of transmigration and global capitalism. How does one engage in death rites and rituals of memorial when no longer spatially proximate the deceased? Cann (2014) explores how survivors in an age characterized by globalization, migration, and increased 
mobility, carry the memory of their loved ones with them, loved ones who have become dis-embodied through the de-emphasis on place-based memorial rituals. Cann's work also focuses on individuated, private modes of memorialization, including tattoos, car decals, and air brushes t-shirts. Though these expressions of grief are theorized in the context of modern capitalism's pressure to grieve quickly, grief sans body must be rearticulated. Just as Vasquez and Friedmann Marquardt (2003) explicate the ways Mexican migrants in the Lower Rio Grande negotiated the "cosmologistical problem" of spatial distance from Our Lady of San Juan, so too do descendants face the cosmologistical problem of ritual obeisance through memorial rites.

The marriage of social inequalities life course literature and religious and ritual studies theories of deathrites creates a fruitful heuristic through which to explore three unique aspects of the contemporary death industry in the United States. While not every theorist discussed above is given explicit reference in the subsequent essays, their insights guided many of my analyses and will continue to inform future work on death, mourning, and memorial.

\section{Layout of Dissertation Essays}

The following dissertation chapters were written with the eventual goal of journal submission. Broadly, each considers different articulations of ars moriendi, the good death, as social reality. Each essay challenges, in different ways, the dominant assumption of ars moriendi as an individual-centered concern. Death is a social process, and steps are taken to achieve ars moriendi are taken well in advance of and after the biological cessation of the specific decedent. The good death is also co-constructed through multifarious social institutions. Each of these essays highlight the interplay of economic, governmental, 
religious, and social influences in constructing proper articulations of deathcare planning, biological cessation, and subsequent bereavement and memorialization.

"They Know What They Want: Natural Burial and the Construction of the Ideal Client" explores the growing popularity of green and natural burial in the United States. Interviews with green burial practitioners were conducted between the fall of 2018 and the summer of 2019 with initial plans to elucidate the role of certifying agencies in the legitimation of green alternatives to consumers. While this remains a component of my analysis, grounded theory (Glasser \& Strauss 1967) allowed me to shift focus to the ways practitioners constructed the ideal green burial consumer through the emergent themes of economic frugality, environmental thoughtfulness, and familial ritual recentering. Navigating a middle ground between business and consumer-related motivations for industry change, I suggest motivations among consumers construct and are constructed by the expectations of practitioners, framing the good (green) death as one centrally concerned for family, finances, and environmental sustainability.

"Fire to Water, Ashes to Ashes: A Comparative Analysis of Fire Cremation and Alkaline Hydrolysis in U.S. Deathrites," the second essay in this set, compares nineteenth and twentieth century debates surrounding fire cremation to contemporary battles over alkaline hydrolysis, also known as resomation or liquid cremation. The process involves breaking down the decedent's body through a combination of hot water and alkaline, which over a several hour period leaves only calcified bone matter that is then crushed to resemble ash cremains. Heralded by environmental groups as significantly more energy efficient than fire cremation, the method has faced fierce opposition across the United States. Currently, only twenty states legally sanction alkaline hydrolysis. Of those states, only a 
fraction currently offers the process. Critics of resomation, particularly religious authorities including the Catholic Church, share many of the concerns for bodily desecration expressed a century ago. Secular political opponents stress discomfort with the dissolution process, wherein liquified soft tissue is disposed in municipal sewage systems. Despite ongoing tensions, state legalization of the process has increased steadily over the past two decades. The slow cultural acceptance of resomation may come to mirror the ubiquity of fire cremation, which went from a fringe process accounting for less than a quarter of U.S. internments in the mid-twentieth century to overtaking bodily burial as the nationally preferred internment method in 2015 (NFDA 2019).

The last essay, entitled "Dying Responsibly: The Good Death as Neoliberal Individuation" investigates the growing industry of deathcare preplanning websites as a site of neoliberal individuation, shifting responsibility for the good death from families, the community, and medical authorities to the individual through rhetorics of individuation, personal responsibility, and unexpected risk. Rather than suggesting the personal investment in one's own funeral arrangements signals vanity, death planning websites reframe consumer motive as one of mercy and thoughtfulness, saving bereaved survivors from the pain and uncertainty of organizing an appropriate memorial without clear knowledge of the decedent's preferences. The specter of untimely death is employed to remind all potential clients - even young clients with no health concerns - that it is never too early to absolve their loved ones of the burden of their possible death.

\section{The Importance of Death \& Dying Studies to the Twenty-First Century}

Each of the topics in this collection speaks to timely articulations of deathcare ritual and the relationship of the living to the dead in the twenty-first century United States. Since 
its inception, the sociology of death and dying has been a relatively niche subdiscipline. It is also a diverse academic space with no fixed method or focus. Many sociologists who describe themselves as death and dying specialists are broadly associated with life course studies, focusing on the gerontological process of aging and experiences at the end of life. Often, these scholars consider the effects of medical centers, senior living facilities, palliative care, and hospice services on macro-structural and micro-interactional levels. A smaller number of death and dying scholars focus on the deathcare industry, specifically (eg. funeral homes, crematoria, and cemeteries). Far more of this work is conducted in interdisciplinary programs throughout the United Kingdom, while many American researchers explicitly focused on post-death industries cluster in anthropology and religious studies networks. Although I attempt to marry sociological and religious studies considerations in my work, there is still a place for uniquely sociological considerations of deathcare. Recent national and global developments speak to the growing importance of death studies from a sociological perspective, each illustrating structural mediations of grief, memorial, and entombment.

One of the focal points throughout these essays is cost. Bloated expenses and upselling seemingly unnecessary services are an endemic feature of the American funeral industry. According to the National Funeral Directors Association, the median cost of a funeral with viewing, burial, and vault in 2020 was $\$ 9,135$, while the median cost of a funeral with viewing and cremation was $\$ 5,150$ (NFDA 2021). In a market defined by high cost, it is understandable that financial barriers significantly hinder survivors' sense of achieving ars moriendi for decedents. Various federal and state programs have been established to mitigate financial hardship stemming from funerary costs resulting from 
certain types of death. Having access to emergency subsidies designed to ameliorate the financial burden of untimely death can have a nontrivial effect on the ability of the bereaved to carry out adequate death rites for their deceased.

\section{Conclusion}

As these three, unique articulations of the good death illustrate, death in the contemporary United States is a social phenomenon affected by multifarious institutional and structural mechanisms, many outside the control or influence of individuals, families, and local communities. Recent contestations of "legitimate victimhood" following Hurricane Maria, ongoing struggles to adequately care for the death in communities affected by gang violence and untimely death, the institutionalization of certifying agencies in the natural deathcare market, and the ascendency of for-profit death preparedness companies all indicate the timely need for a sociological investigation of the good death and its numerous articulations in the United States. 


\section{Ch 2. "They Know What They Want" Natural Burial and the Construction of the Ideal Client}

\section{Introduction}

American deathcare consumers are going green. According to data from the National Funeral Directors Association, over half of the population is interested in exploring natural burial options (NFDA 2019). Beginning in the United Kingdom in the

early 1990s, this growing consumer receptivity is part of trend challenging conventional burial methods. Kelly (2015) defines conventional burial as "whole-body burial with the use of chemical embalming, sealed hardwood and metal caskets, and reinforced concrete vaults and liners." As demand for alternative internment options grew, coupled with increasing frustration and suspicion of conventional methods, extant cemetery grounds and new conservation properties began offering natural services for the deceased, which consist of preparation and burial without embalming chemicals, biodegradable caskets or shrouds, hand-dug graves, and natural grave markers.

From the fall of 2018 to the summer of 2019, I sought the expertise of natural burial practitioners across the United States to better understand the growing popularity of natural burial options. During data collection, themes emerged in the language used by natural burial practitioners to discuss the motivations of decedents and their families. Using the constant comparative method (Glaser 1967), focus shifted from the practice of natural 
burial in the United States to how practitioners, through their explanations and expectations of consumer motivations for natural burial, co-construct the ideal natural burial participant and family. Social construction of the ideal "natural burial consumer" is occurring at a moment of shifting societal death systems, defined by Kastenbaum and Moreman (2018) as the web of interpersonal, cultural, and symbolic networks that inform societal attitudes toward death, dying, and the corpse.

While practitioners play a key role in the construction of the ideal natural burial customer, their framing is not absolute. Hockey et al (2012) elucidated important areas of tension and negotiation between the goals and motivations of natural burial advocates, landowners, and customers. With this warning in mind, we can nevertheless see how natural burial practitioners construct ideal deathcare consumers in three important ways. First, the ideal deathcare consumer is economically informed, fed up with the high costs associated with conventional disposal. Second, the ideal natural burial customer is environmentally conscious, rejecting the ecological dangerous of chemical embalming and land misuse associated with large headstone, durable caskets, and large cement vaults. Third, the ideal natural burial customer does not act alone. Rather, natural burial recenters a family ecology of deathcare (McIlwain 2003) through agentic participation of family and friends in the preparation and internment processes of natural burial.

\section{The History of Contemporary Internment and Natural Burial Scholarship}

The rise of natural burial alternatives in the United States does not represent a transition to new methods of deathcare but rather a return to practices commonplace prior to the mid nineteenth century (Kelly 2015). Embalming was a chemical innovation initially reserved for laboratory dissections, involving both animal and human cadavers, making its 
way to the United States in 1840 (Laderman 1996). It was not until the American Civil War that embalming became a common process for preserving bodies for burial. The war presented a unique problem, particularly for Northern families who wished to transfer the remains of their deceased loved ones for burial at home. Given the conventional methods of the time, it was impossible to transport Northern war-dead in time for burial before significant decomposition. Embalming, championed by a new class of experts and traveling undertakers, provided a reliable, though not yet perfected, means of interstate transposal (Gilpin Faust 2008).

Following the very public death tour of Abraham Lincoln's embalmed corpse in 1865, chemical embalming became the commonplace means of preserving and displaying the deceased for ritual viewing prior to internment (Laderman 1996). As attitudes shifted away from embalming as bodily defilement to a necessary precaution against the polluting corpse, it became an unquestioned step in the process of death throughout much of Europe and the United States (Slocum \& Carlson 2011). Aside from a boom in cremation rates following guarded Catholic acceptance of the practice in the Second Vatican Council (Prothero 2001) and the release of Jessica Mitford's (1963) scathing exposé of the funeral industry the following year, conventional embalming went largely unchallenged for much of the twentieth century.

The contemporary natural burial movement began in the United Kingdom with the establishment of the NBM in 1991 (Hockey et al 2012). Embalming fluid and its deleterious effects on the environment was the primary motivation for enacting government policy to allow for the natural internment of dead bodies (Stowe Jr 2001), which became an officially recognized mode of disposal in 1993 (Hockey et al 2016). Given the genesis 
of the contemporary natural burial movement in the United Kingdom, it is no surprise much of the scholarship on natural burial is UK-based. Clayden and Dixon (2007) explored the utility of trees as natural woodland markers in natural burial sites, positing the durability and grow of an intentionally planted arboretum memorial strengthens memory and promotes a lasting, felt connection to the dead. Conversely, Hockey et al (2012) suggest that natural burial sites devoid of permanent markers help the bereaved make sense of absence brought about by death through the literal absence of physical grave markers and an emphasis on natural landscape seemingly devoid of human interference.

Shifting focus from landscape to participants, MacMurray and Futrell (2019) highlight the role of Ecological Death Advocates (EDAs), including practitioners, advocates, and spiritualist reformers, in promoting an "ecodeath ethic" that strives for deathcare decisions based on ecological concerns and shifting attitudes about death. Still others have explored the emotional dimensions of natural burial participation among clients and practitioners (Ingold 2000; Powell et al 2011). The dearth of studies on articulations of natural burial and the concerns of natural burial participants in the United States represents a significant gap in the sociological literature on death and dying.

\section{Method}

This study employs the elite interview method (Holstein and Gubrium 1995). The elite interview method allows researchers to identify specific experts with unique insights into a phenomenon, requiring rigorous and potentially complicated scheduling, as elite interviews are often hard to establish given the relative importance, scarcity, and busy schedules of high-level experts. Phone interviews were conducted with 22 practitioners in the natural and green burial industry from the fall of 2018 to the summer of 2019. This 
sample included practitioners from every corner of the United States. Cemeteries designated "green" or "natural," whether by their own promotional materials or through centralized green burial databases, exist in all fifty states and the District of Columbia. Interview subjects were identified in consultation with multiple online databases, including US Funerals Online's Green Burial Directory and the Green Burial Council's database of GBC certified cemeteries. Cemeteries were not filtered for a specific type of green designation. Practitioners represented both fully green repositories and those managing hybrid cemeteries, offering both natural burial and traditional burial options.

Relaying on internet databases for cemetery listings has its drawbacks. First, smaller cemeteries with little online marketing are underrepresented. However, interview subjects were not drawn from these databases exclusively. Roughly a quarter of subjects were collected through snowball sampling. Biernacki and Waldorf (1981) describe snowball sampling as a method of using experts within a social or professional network to recruit others within an industry that may otherwise be difficult to access. This difficulty is particularly salient in networks with niche expert knowledge. The natural burial industry is a relatively small community with significant interaction between practitioners. Upon completion of the interview or during relevant discussions, interview subjects offered the names and contact information of others in the industry, particularly practitioners and advocates in their region (i.e., within their state or a bordering state).

\section{Findings: Three Emergent Themes}

Interviews were not initially conducted with the intent of focusing on the construction of the ideal green burial consumer. Rather, preliminary plans centered on the role of certifying agencies in the legitimation of green burial alternatives. During the 
process of conducting interviews, several themes emerged during discussions of consumer motivations that became difficult to ignore. Once interviews were conducted and data analyzed, these themes were deemed a more fruitful path than the initial research question. The following themes are the most universally offered by practitioners describing the motivations of potential green burial consumers. Overwhelmingly, practitioners constructed the ideal consumer as one concerned with the high costs associated with the traditional funeral industry, the environmental impacts of embalming and fire cremation, and the waning focus on family and community authority in deathrites. These are concerns the ideal consumer brought with them to the deathcare market. As a green burial practitioner in Wisconsin described, "[t]hey know what they want" (2019).

\section{Cost: The Informed, but Not Cheap Consumer}

Natural burial sites are not uniformly cheap alternatives to conventional burial (Clayden et al 2010). Some natural burial sites offer one fixed-cost for any burial on their grounds, while others charge variable amounts based on location or proximity to natural landmarks, eg. old trees or hilltops. Regardless, natural burial practitioners framed the decisions of individuals and families to elect green alternatives as primarily financial. All the specialists interviewed described consumer frustration with dominant burial norms. According to the National Funeral Directors Association, the median cost of a funeral with viewing, burial, and vault in 2021 was $\$ 9,135$, while the median cost of a funeral with viewing and cremation was $\$ 5,150$ (NFDA 2021). Specialists constructed the green consumer as one who is fed up with the high costs of unnecessary procedures. Their criticism was most often directed at the process of embalming. As a practitioner in the Pacific Northwest put it, 
It's pretty clear that families are tired of the high cost of a traditional burial. They're looking for cheaper alternatives that are also more environmentally friendly. They're asking if they really need things like embalming or a vault. More and more people are realizing these aren't things they need to celebrate their parent's life, or their life (2018).

Researchers have suggested deathrites often serve as one final articulation of material inequality (Smith et al 1992; Park 1994; Banks 1998; Harris 2007). Memorial as a social process is as much an illustration of the social and economic capital of both the decedent and their families as it is a rite meant to commemorate the dead. Funerals, memorials, wakes, and burials provide survivors an opportunity to display their financial superiority through the purchase of ornate coffins and vaults, large or intricate headstones, ritual decorations, and the inclusion of specialty acts at the time of internment, including musicians or dove handlers. By centering austere economic concerns, green burial specialists suggest a rearticulation of deathrite priority. The archetypal green burial consumer rejects the material spectacle so often associated with memorial practice.

At the same time, practitioners illustrated a concern for overgeneralizing economic motivations. When referencing the exorbitant costs associated with the average burial and ceremony, practitioners pivoted to adjacent concerns, including those discussed below. This desire to pair financial calculi with other justifications (eg. environmental concerns, burdening the family, simplicity) may be a response to the anticipated judgement of weighing deathcare options monetarily. Thrift in disposal and memorial has long been a socially unacceptable rationale for bereaved families and friends in the United States, signaling a lack of connection with or care for the decedent. 
By framing financial concerns as central but never exclusive, natural burial practitioners present an informed consumer who rejects unnecessary cost rather than cost as an indication of value or concern for the decedent. The above quotation illustrates this point. After stating that families desire "cheaper" alternatives, he shifted the focus of financial concern to necessity, citing superfluous practices like embalming or the purchase of a large expensive vault for internment. Tina, a practitioner from the East Coast, similarly emphasized unnecessary practices contributing to higher costs while pairing that frustration with a broader concern for the environment, discussed more explicitly in a later section. "Why would I want my family to spend all this money to fill me with chemicals? Why do I need a fancy casket? I'm not going to see it!” (2019). Here, Tina challenges the value of social exchange in deathcare by rejecting the idea that she is an active participant after death. She questions why her family should exhaust financial resources on something she will never see, i.e., when she is dead. Still, she does not suggest that her physical absence absolves her family of all deathcare obligations. As a practice marred throughout contemporary US history by opaque cost structures, requirements, and billing practices (Mitford 1963; Beard \& Burger 2017), a regard for price presents these consumers as significantly more informed than the average American.

\section{Environment:}

Given the genesis of the contemporary natural burial movement in the United Kingdom and United States as responses to environmental degradation, it is no surprise that environmental concerns were universally offered as a primary motivation for natural burial consumers. Practitioners construct ideal decedents and their families through a rejection of waste and pollution generated by conventional means of disposal. Practitioners 
often framed the decision to elect natural burial as an extension of a lifelong concern for the environment. Several interview subjects pointed to the aging Baby Boomer generation, those born from 1946 to 1964 , as a reason for the increased popularity of natural alternatives. Many Boomers who took up environmental concerns in their youth are now acting on those concerns through their choice of deathcare practices. As a practitioner in the Pacific Northwest said, "We see more and more Baby Boomers entering that phase of their life. They're dying or thinking about death more. This was the hippie generation, so many of them still have those concerns about the environment" (2018). These preferences may be made explicit to family and friends, or survivors may approximate the supposed wishes of a decedent through inference.

Although embalming has been the primary target of environmentalist critiques of conventional burial practices in the United States, practitioners also emphasized the recognition among decedents and their families that cremation, the most visible alternative to embalmed burial, has its own environmental drawbacks. Cremation removes some environmental impacts of burial, such as the seepage of embalming chemicals into the ground and the use of heavy concreate vaults for internment but contributes significant air pollution in the form of $\mathrm{CO}_{2}$ emissions. Despite significant state-level variability in cremation rates (Harrington \& Krynski 2002), the projected cremation rate in the United States was $56 \%$ for 2020, according to the National Funeral Directors Association (NFDA 2021), a significant increase from the turn of the millennium when roughly $25 \%$ of deaths in the United States resulted in cremation (Prothero 2001). As cremation rates continue to climb, practitioners set the eco-consciousness of their clients apart from a generalized rejection of embalming and bodily burial. According to a practitioner in Wisconsin, 
"People are starting to pay attention to work we're burning up. It takes a lot to cremate a body, but there are also things inside bodies that aren't great [to burn]... hip replacements, heart valves. All of that stuff has to go somewhere" (2018).

Environmental concerns need not be reduced to the level of individual preferences. According to some practitioners, the decision to dedicate a natural burial cemetery itself may stem from broader environmental goals. Depending on state-level policies, several natural burial practitioners referenced land conservation as an explicit justification for natural burial. Coutts et al (2018) define natural burial land conservation two ways. First, burying an unembalmed body in a biodegradable coffin or shroud facilitates the densification of extant cemetery grounds in ways that are untenable when using large burial vaults made of cement, granite, or marble. The need for and inefficiency of cemetery space is best illustrated through United States Geographical Survey data. There are roughly 150,000 places designated as current and historical cemetery spaces throughout the United States. However, just under 25,000 of these spaces were active, or taking new burials, in 2020 (NSGS 2020). While some of these burial sites are inactive due to abandonment, far more are simply at capacity. Natural burial allows for a significant number of burials in closer proximity. Digging burial plots by hand, another requirement of a fully natural process, further controls for the potential disruption of previously interred bodies with much more precision than achieved by a backhoe, mitigating one concern of densification.

In addition to the concern for maximizing land use within extant cemeteries, natural burials on new sites also serve as a form of environmental protection through the creation of conservation easements - legal agreements to restrict the use of land in perpetuity. Many natural burial cemeteries established on conservation easements use these arrangements as 
an important part of their marketing strategy, transparently explaining how fees and costs of burial will be used to maintain the land. A large conservation cemetery in the Southeast explains the process on their website, stating:

A portion of each burial fee is committed to pay for land acquisition, protection, restoration, and management. The burial area also becomes hallowed ground, restored to its natural condition and protected forever with a conservation easement. Native plants beautify the burial sites. Those who support conservation are offered a more meaningful burial option with the certainty that protected land is the ultimate legacy to leave for future generations. Families and friends are brought closer to nature in the commemoration of their loved one's life (Prairie Home Conservation Cemetery 2021).

Practitioners expressed concerns for conservation at numerous points in the interview process. For some, the natural burial site was started through an easement, while others used conservation easements to acquire further land. In several cases natural burial locations were chosen for their proximity to public conversation sites, including state forest and wildlife centers. According to a practitioner in Washington State, some decedents and their families seek out these cemetery grounds due to their history with local environmental causes and their love of the landscape, including adjacent public lands. "We have had a few folks buried up here because they did a lot of hiking in the area. I know a handful of people who are still alive but plan to be buried here for that same reason" (2018).

Many Americans pick a cemetery plot or set of family plots with a concern for the surrounding aesthetics (Burial Planning 2021). Some also elect alternatives to embalmed burial, including fire cremation, out of a professed concern for the environment. But for 
these natural burial practitioners, the natural burial client extends these concerns to a higher level of eco-consciousness; one that prioritizes, and in some cases subsidizes, the environmental mission of the natural burial cemetery. These customers are assumed to have done their homework, comparing alternatives to embalmed burial in the case of electing against cremation, and investigating the political landscape of conservation easement in the case of proper land utilization.

\section{Recentering the Family}

The role of family in the deathcare process is a central focus of death and ritual scholars. Shifting authority (Walter 1994) and an increased emphasis on expert systems (Giddens 1990) resulted in a devaluation of the role of family, friends, and community in the processes of caring for, preparing, and disposing of the dead. In the American context, Laderman (1996) points to the routinization of embalming in the funeral process as leading to the rise in the professionalization and medicalization of deathcare work. As the process of navigating the funeral industry became increasingly opaque, families found themselves with a diminished awareness of the choices available to them during internment and memorial planning (Powell 2011).

Natural burial practitioners lament the loss of familial involvement by positing the choice of natural burial as one informed by a desire to reclaim the central role of the family in burial preparation and interment, referred to by Bouverette (2017) as the deinstitutionalization of death. Every interview subject paid significant attention to the role of the family in selecting a natural burial option. Many pointed to a growing unhappiness with the professionalization of death and the total reliance on specialists to care for loved ones. As an interview subject from New Jersey said, "I think people are tired of handing 
their [deceased] family over to someone else. They don't want to be so hands off' (2019). Many natural burial cemeteries throughout the United States include willing family and friends throughout the funeral process. Family help clean, dress, and apply makeup to the decedent. They will also carry or walk with the biodegradable casket or shroud to the cemetery plot. In some cases, family members may even dig and refill the burial hole.

In the first half of the twentieth century, funeral directors lauded their ability to carry the burden of deathcare obligations for grieving survivors through their newly professionalized services (Laderman 2003). By the end of that century, some families were pushing back, reclaiming the ritual importance of family involvement. Echoing scholarly explanations of contemporary Western attitudes toward death (Aries 1974), practitioners occasionally described their initial surprise at the enthusiasm many family members display when provided an opportunity for involvement in the deathcare process. "You'd think families would be uncomfortable, but I would definitely say far more people want to be involved than don't. They want to dress the body or help dig the grave, help fill it in" (2018).

Centering the family in all aspects of the natural burial process also aids in demystifying the process of death for the contemporary survivor. Social theorists have defined the late modern era through the privatization of medical processes and the sequestration of experience (Giddens 1991; Mellor \& Schilling 1993; Seale 1998). This includes the processes of death and mourning, in which both events are hidden from public view. Hockey et al (2016) advance a theory of natural burial as challenging the sequestration thesis of death by actively engaging the bereaved. This sentiment is echoed by a practitioner in Washington State: 
We spend our whole lives making decisions with our families. When you think about it, it's a bit strange to leave the last and maybe most important transition in someone's life to strangers. There's more trust in the process when family is involved. Less detachment from what's happening. I think families don't even realize that's been missing until they help with a green burial (2018).

Giddens rightly articulates the ascendent role of expert systems that "bracket time and space through deploying modes of technical knowledge which have validity independent of practitioners and clients who make use of them" (1991). However, he characterizes this arrangement as one predicated on willful, albeit blind, trust in systems the novice finds inaccessible. Unfortunately for the American deathcare industry, Mitford's (1963) scathing exposé of nefarious funeral directors and profit-driven grief counselors left an indelible skepticism. For some, active involvement in the funeral process mitigates these concerns, providing a transparency practitioners claim is absent from conventional methods of preparation and internment.

\section{Discussion:}

Natural burial practitioners play an active role in the social construction of their ideal clients, framing their motivations as primarily revolving around three concerns: cost, environment, and family. Across 22 interviews from every corner of the United States, these three themes were consistently referenced as foundational reasons for the proliferation of natural burial options over the past two decades. But from whom do these priorities derive? What role do practitioners themselves play in centering these three concerns for their decedents and families? 
Practitioners' perspectives on clients' economic frugality illustrate well their role of in framing a practical cost-saving concern within a broader indictment of the conventional funeral industry. Many critics point out the relative ignorance of survivors when faced with the lose of a loved one (Mitford 1963; Kopp \& Kemp 2007; Audebrand \& Barros 2017). These critics claim that this potent mixture of ignorance and grief form the primary mechanisms by which the conventional US funeral industry engages its historically nefarious practices. To be sure, some decedents and families may have intimate knowledge of the significant costs associated with conventional burial, but with little policy change since the time of Jessica Mitford, many argue that the industry remains as opaque as ever. How then, might practitioners project their own critiques of the industry they ostensibly seek to undermine? By placing the onus of economic frustration on the part of clients, practitioners craft a consumer-driven backlash to the detriment of the traditional funeral industry while positioning themselves as the financially savvy, but never dismissively cheap, internment alternative.

Emphasizing environmental concerns as central to the decision-making process of decedents and their families strengthens affiliatory identity with natural burial, shifting its status as not only one option among many in the deathcare marketplace, but as the singular ecological choice for Americans suspicious of unnecessary embalming chemicals and innumerable quantities of metal and concrete buried in cemeteries throughout the country. The weight of this environmental message is illustrated through the prominence of certificatory agencies such as the Green Burial Council, who certify natural burial sites across several tiers of ecological impact: hybrid cemetery, natural burial grounds, or 
conservation burial grounds. To qualify for certification, natural, conservation, and hybrid cemetery grounds much meet at least 16 standards set forth by the agency (GBC 2020).

When asked about the role of the Green Burial Council in the natural burial industry, many practitioners were ambivalent. As the owner of a large, GBC certified cemetery in the Midwest noted, "No one needs to be certified. If you're green, you're green. The Council has no authority" (2018). Others noted the mutual dependency of natural burial sites and the GBC, claiming that the latter sought out certifiable applicants as much as certifiable applicants contacted them for appraisal. The relationship was often described as co-dependent - GBC certification legitimated the status of natural burial sites in the eyes of their clients, but certification from the GBC was only viewed as legitimate because natural burial sites agreed to be certified and listed through their online database of GBC cemeteries. Regardless the nature of the relationship between the agency and cemetery practitioners, certification and the rhetorics of eco-consciousness facilitated the construction of natural burial decedents and their families as equally invested in natural burial as a site of environmental activism.

The centrality of the family in the burial process through a deinstitutionalization of death challenges Walter's (1994) three-part typology of deathcare attitudes and identity. While there are notable, valid critiques of Walter's distinctions between traditional and modern stages, the biggest challenge to his framework by the natural burial process is levied against his contemporary shift from modern to neo-modern death. The central role of family and community wane, according to Walter, as societies move through traditional and modern attitudes toward death. However, rather than reestablishing the importance of the family in his final neo-modern stage, authority shifts from experts to the individual, 
relegating the family to passive agents tasked with carrying out the predetermined wishes of the decedent. While the personal preference of the decedent is no doubt an important aspect of the ascendency of natural burial options across the United States, these practitioners place as much, if not more, emphasis on the agentic role of the family in deciding and carrying out natural burial practices. Survivors as not simply consulted. Rather, they are centered in the preparation and burial rituals on natural cemetery grounds. Practitioners rarely discussed family preferences outside of the context of the decedent, and at no time did interview subjects suggest individuals were prepared and interred naturally against their wishes. Still, further research should explore the role of family decision making apart from the known wishes of the deceased. Not only it is important to know how eco-conscious families navigate deathcare options when the wishes of the deceased are unknown, but also whether there are instances of family members projecting their own preferences where none were given. This would suggest a far more participatory role for the family and community than Walter allows.

\section{Limitations and Directions for Future Work}

Entry into the natural burial market is quite dependent on the availability of reliable cemetery databases. During data collection, multiple databases were used to find natural burial grounds in all fifty states and the District of Columbia. However, there was much variability between lists. Additionally, the cemeteries featured on these databases, whether entirely natural or hybrid, skewed to larger commercial operations. Small, independently run properties and conservation easements were significantly harder to find and contact. Future work should include cemeteries and practitioners with limited or no online 
exposure. It is possible these smaller operations engage in less overt framing of the ideal natural burial customer or frame these clients with less uniformity.

Future work should also focus on the ways potential and current clients view themselves. As Hockey (2012) notes, the natural burial process is a constant negotiation between advocates, landowners, and customers. Practitioners are uniquely situated as spokespeople and public educators for the natural burial industry. Scholarship should not ignore the ways practitioner interests may inform their public-facing portrayal of the industry, its clients, and their motivations.

\section{Conclusion}

The natural burial market in the United States is still relatively small but growing. As survey data from the National Funeral Directors Association indicates, roughly $51 \%$ of Americans express interest in natural burial options for their own internments (NFDA 2019). The explosion of cremation rates in many parts of the United States since the turn of the millennium illustrates of how quickly Kastenbaum and Moreman's (2018) societal death systems develop and adapt. Recent state-level policies, including Washington State's approval of SB 5001 legalizing natural organic reduction, commonly referred to as human composting, and liquid cremation through alkaline hydrolysis, point to new horizons in American deathcare (Kiley 2019). Overwhelmingly, these developments offer environmentally conscious alternatives while reducing costs associated with conventional burial. At the same time, the shift toward, or return to, natural burial processes illustrates a waning of fear surrounding the corpse that has informed much of the scholarship on contemporary death and dying (Aries 1974; Walter 1994). New theorizing will be required 
to make sense of these practices, the clients who engage them, and the practitioners who advocate for a growing industry that challenging convention.

Ch 3. Fire to Water, Ashes to Ashes:

\section{A Comparative Analysis of Fire Cremation and Alkaline Hydrolysis in U.S. Deathrites}

\section{Intro}

If one topic shocks undergraduate students while discussing contemporary forms of internment, it is alkaline hydrolysis. Commonly referred to as liquid cremation, aquamation, or resomation, alkaline hydrolysis is a process of dissolution involving a mixture of heated water and small amounts of alkali that breaks down bodily remains in a matter of hours, leaving only calcified bone material that is then broken into a powdery substance resembling traditional ash cremains. It is not the cremains that shock students, but rather what happens with everything else. Soft tissue is liquified and drained, typically into local sewer systems. These moments of abject shock and disgust, usually exemplified by a series of open mouths and wide eyes, provide an excellent opportunity to discuss the social construction of deathrites, more generally, juxtaposing historical reactions to internment practices now viewed as entirely common or even boring. This is one such example. Using nineteenth and twentieth century arguments for and against the rise of fire cremation in the United States, I draw cognates to contemporary controversies, including 
religious, economic, and legal arguments, surrounding the growing popularity of alkaline hydrolysis as an environmentally friendly internment alternative.

Human disposal through alkaline hydrolysis is currently legal in twenty U.S. states, doubling over the last decade (Solomon 2020). However, regulation of the process and legal designations of appropriate alkaline hydrolysis practitioners vary widely (Olson 2016). Comparative historical analysis of between-case controversies surrounding fire and liquid cremation, as well as the within-case religious, economic, and political arguments for and against alkaline hydrolysis at the state level elucidate the ways deathrites and mortuary practices operate within a complex web of social institutions and shifting cultural norms. Of the ten U.S. states with the highest proportion of Catholic residents, only Illinois (tenth highest proportion) has legal and readily available resomation options.

This analysis is guides by several important questions. First, how did fire cremation go from a fringe alternative throughout much of the twentieth century to overtaking embalmed burial as the most preferred internment method in the United States by 2015 (NFDA 2019)? Second, what role did religious institutions and policymakers play in these significant shifts? Finally, how are these same social institutions shaping the current alkaline hydrolysis debate and does this give us a window into where the practice might be in the coming decades?

\section{Literature Review}

The biological cessation of life is only one aspect of death. Death is also a social process contingent upon complex associations between decedents, bereaved survivors, religious and legal authorities, and a web of expert systems in the health and deathcare industries. As such, significant scholarship has mapped the social-structural dimensions of 
deathcare practices across time and space, stressing the macro relationship between fear or acceptance of death with prevailing mortuary customs (Aries 1974; Seale 1998) as well as the relationship between social identity, ritual, and authority (Walter 1994).

Theorizing the relationship between industry forces and consumer attitudes represents a central tension among scholars of the deathcare industry. Beard and Burger (2017) categorized contemporary trends in the U.S. deathcare industry in two ways: Business-Related Motivations (BRM) and Consumer-Related Motivations (CRM). The former, exemplified by Mitford's (1963) analysis of the funeral industry, posits a top-down influence of industry experts on consumer behavior. Customers want increasingly complex (and expensive) cremain reliquaries because this is what salespeople suggest as essential to the grieving process. Given the lack of empirical support for these claims (Birrell et al 2020), BRM scholars often suggest nefarious intent among industry experts in the pursuit of profit. The CRM approach, supported by Laderman (2003) and Davies (2015), suggests changes in the deathcare industry are primarily driven by consumer desire and cultural trends. In this articulation, deathcare companies offer increasingly complex (and expensive) cremain reliquaries because this is what the customer wants. Consumer-driven scholars also accuse Mitford and others focused solely on top-down business interests of being far too cynical and blind to the role of consumers in the process of industry change.

Rebay-Salisbury (2012) challenges the BRM model by focusing on the role of belief in shaping dominant deathcare practices. Belief is differentiated from an overtly religious orientation as a more general set of assumptions about the body, death, and the afterlife that are "constructed in communication and enacted by society, relating to how people think about the world and how they make it understandable in their own terms, 
striving for order and reason about aspects of life which are beyond their control." Shifting cultural attitudes about cremation informed by epistemic tensions between Enlightenment forces and the Roman Catholic Church constitute one dimension of the relationship between belief and mortuary practices.

The specific effects of religious practices on broader deathcare trends was explored by Walter (2017) who proposed four potential relationships between religious mores and deathcare practices. First, religious institutions may promote deathcare practices that then become normative within society. Second, opposition may occur when emerging deathcare practices are perceived to contradict religious norms. Third, authorities or laypeople may engage in religious accommodation after brief or prolonged opposition to specific practices by adjusting rules through subsequent exegesis of religious texts and institutional tradition. Finally, if dominant religious institutions fail to provide adequate outlets for grief, bereavement, and dispossession, society may engage in deathrite compensation. The slow social and religious acceptance of cremation in the United States over the twentieth century, as well as contemporary debates over the permissibility of alkaline hydrolysis, provide clear illustrations of all four of these religious and societal approaches to deathcare.

Much contemporary social science scholarship on the social acceptance of contemporary deathrites comes from Europe. Despite thoughtful challenges to state-level comparisons as the most meaningful analysis of cremation attitudes across Europe (Colombo 2017), national differences in cremation rates remain a strong representation of historic religious influence, with traditionally Protestant nations reporting significantly higher rates of cremation relative their traditionally Catholic neighbors (Davies 1996). Many continue to use secularization as an explanatory mechanism for deathrite evolution 
in Europe (Warpole 2003; Palánová et al 2015; Breschi et al 2017). Challenging the explanatory power of secularization, de Spiegeleer (2019) uses recent deathrite trends in Belgium to nuance extant theories that suggest an increasing secularization of funerals and deathcare throughout Europe are the result of anonymous processes of modernization, instead viewing these changes through the lenses of conflict theory and subsequent competition among market-actors filling newly vacated roles previous occupied by strong, central religious authority. Scarce academic work exists on attitudes toward alkaline hydrolysis, as it is still prohibited throughout much of Europe (Robinson 2021).

In contrast to Europe, the United States has confounded grand theses of secularization for the last century, leading to divergent theorizations of deathrite practices through the lens of religious renewal (Garces-Foley \& Holcomb 2006). U.S. deathrites also exhibit notable differences in deathrite preference along religious, class, and racial lines. Orpett Long et al (2017) challenge Walter's (1994) assertion that twenty-first century deathrites center the wishes of individual decedents by exploring the tensions expressed within interreligious U.S. families, illustrating the complexity and controversy navigating potentially incongruous religious prescriptions. Racial differences in the acceptance or rejection of cremation as a viable form of internment have also been reported (Glass \& Samuel 2011; Buchanan \& Gabriel 2015). Harrington and Krynski (2002) argue that cremation rates vary across U.S. states based on the level of industry regulation, finding lower rates of cremation in states that require funeral directors to be certified embalmers and for funeral homes to have embalming preparation rooms on their premises.

At the heart of many arguments surrounding the care and internment of the human body is a concern for pollution. Discussed below, Sanitarians, U.S. cremation advocates at 
the turn of the twentieth century, made public appeals for mortuary reform drawing on the miasmatic theory of bodily contagion (Prothero 2001). Likewise, contemporary opponents of alkaline hydrolysis express dismay at the potential environmental degradation of municipal water supplies through the dissolution process. While some of these concerns have been dismissed through scientific advancement (eg. germ theory as a replacement for miasma), a general concern for contamination is not without warrant. Gwenzi (2021) conducted a metanalysis of toxic organic contaminants (TOC) recorded in autopsies, thanatopraxies, cemeteries, and crematoriums to conclude that deathcare sites serve as hotspots of ecological and biological health risk. Rumble et al (2014) suggest new deathcare practices have blurred the lines between the living and the dead, shifting from disposal of remains in specially sectioned off spaces for the dead to dispersal of remains through environmentally conscious contemporary practices including the spreading of ashes, human composting, natural burial, and alkaline hydrolysis. Tavares de Cruz et al (2017) found that the dispersal of remains at a site of one's choosing, as well as the environmental benefits of contemporary practices are among the top reasons Brazilian mourners support new deathrite practices. Similar results were found among U.S. environmentalists (Stock \& Dennis 2021).

\section{History of Cremation and Sanitary Reform}

A specific catalyst for American cultural awareness of industrial cremation as a form of internment is not known, but scholars point to an 1874 Contemporary Review article entitled "Cremation: The Treatment of the Body after Death" as a likely influence (Thursby 2006). The first modern cremation in the United States took place in 1876 in Washington, Pennsylvania when Baron Charles De Palm, an Austrian immigrant and 
member of the Theosophical Society, elected the procedure on his deathbed. Although his exact motivations are unknown, the notoriety his death garnered, as well as the six months it took to procure a proper crematory by Dr. Samuel LeMoyne, laid the groundwork for the slow acceptance of cremation beginning roughly a quarter century later (Rosen 2004). Cremation advocates fought their battle on several fronts. First, Sanitarians painted the human body as inherently polluting and the presence of cemeteries in and near cities as an overt health risk. Advocates built their argument around miasma theory, a precursor to germ theory that suggested decaying organic matter produced noxious emissions thought to be the genesis of many illnesses and epidemics (Duffy 1990). Cutler and Miller (2005) argue that miasma theory relied on a Pavlovian association between foul smells, dense urban centers, and sickness. Sanitarians proposed sweeping reforms to mitigate the assumed effects of unhygienic conditions, and methods of memorial and internment were no exception.

Leading miasma theories of sickness may have alleviated popular anxiety on scientific grounds, but it did nothing for American Christians who objected to the practice for theological reasons. Cremation was officially outlawed by the Catholic Church in 1886 as part of ongoing tensions with Italian Freemasons who championed the practice in open, anti-clerical antagonism. This position intensified in 1892 when Catholic priests were forbidden from giving last rites to any person intending to be cremated following death (Knight 2018). In the U.S., the most common argument faced by cremation advocates came from Catholic (and some notable Protestant) resurrectionists who considered the body central to resurrection on the day of judgement (Prothero 2001). Many Catholic Church leaders freely admitted they could not find definitive condemnations of cremation or 
explicit directives for burial within the Hebrew Bible or New Testament. They also held that God could easily return ash to material form. Instead, they condemned the intent of cremation, which they perceived to be a rejection of God's ultimate authority. God could return cremains to material form for resurrection, but pious Catholics should not challenge His ability to do so. Cremation also threatened the necessity of numerous related rituals and clerical sacraments, potentially weakening the central importance of the Church. Resurrectionists were troubled by a growing schism among Christians between a waning emphasis on the material body central to Christian theology for much of Church, and the growing primacy of the immortal soul, separate and distinct. An explicit emphasis on bodily resurrection and religious animus toward cremation further served to illustrate the theological rift between Catholicism and Protestantism.

Most American Protestants did not share the concern for bodily resurrection, but many still cautioned against the normalization of cremation. They argued that the practice, along with its newly transportable memorial artifact, may lead to idolatrous veneration of cremated remains, as well as strife over familial inheritance of decedent reliquaries. Even Protestant communities that harbored historical antipathy toward Catholic concerns for the body worried cremation signaled too comfortable a rejection of the body for a transcendence too akin to pagan spiritualism (Prothero 2001).

Two major events significantly shifted American attitudes toward cremation in the 1960s. The Second Vatican Council officially recognized fire cremation as an acceptable form of internment in 1963. Stressing the continued preference for burial and the centrality of the material body for resurrection, the Catholic Church amended their roughly eightyyear ban on the practice if circumstances made cremation the most viable deathcare option, 
decreeing "[t]he Church permits cremation, provided that it does not demonstrate a denial of faith in the resurrection of the body" (USCCB 2019). Additionally, they maintained the necessity of funerary rituals that honored the body prior to burial (Prothero 2001). More recently, the Congregation for the Doctrine of the Faith issued the instruction $A d$ Resurgendum cum Christo in 2016, further clarifying the acceptability of cremation, so long as remains were subsequently interred in a cemetery or other sacred site (Holy See Press Office 2016).

Later that year, Jessica Mitford published the American Way of Death, a journalistic account of disreputable sales practices rampant in the mid-century American deathcare industry. The book was a cultural phenomenon, exposing readers to an industry that historically exploited the ignorance of grief-stricken survivors to drive up funeral costs and sell unnecessary amenities. While the book may not have led to the governmental intervention for which Mitford hoped, it did have a lasting effect on consumer attitudes toward cost and what she deemed "frivolous" ritual, including embalming and casketed burial (Laderman 2003). At the time of the book's publishing, cremation accounted for less than 5\% of all burials in the United States. Over the following half century, that rate would dramatically increase, ultimately becoming the internment method of choice in 2015. In her posthumously published The American Way of Death Revisited, Mitford dedicated a new chapter to the growth of American cremation, lamenting that it had "become just another way to make a buck" through the sale of high-priced urns and niche products (Mitford 1998). Mitford was cremated in 1996.

\section{The Contemporary Battle Over Alkaline Hydrolysis}


There is virtually no federal oversight of the American deathcare industry, electing instead to leave regulation to individual statehouses and agencies. Critics have pointed to this piecemeal arrangement as the source of many nefarious business practices among funeral homes and cemeteries across the country (Slocum \& Carlson 2011). This also leaves each U.S. state to determine, among other things, which internment methods will be legally recognized and available within their borders. Since the early-2000s, some states have debated, passed, or rejected legislation to legalize alkaline hydrolysis. In each case, the unique religious, economic, and political context of the state has helped determine popular support and legislative backing for new or extant internment laws. Proponents of alkaline hydrolysis are split on how to define and advocate for the novel internment method. CANA, the Cremation Association of North America, added alkaline hydrolysis to its definition of cremation processes in 2010 and supports expanding extant statutes to include the process (CANA 2019). On the other hand, the National Funeral Directors Association advocates for unique legislation classifying and regulating alkaline hydrolysis as a new and separate deathcare practice, saying customers could be misled regarding the dissolution process if it is not carefully defined (NFDA 2011).

The first state to legalize the process for human commercial use was Minnesota in 2003 (Atkin 2018b). The status of alkaline hydrolysis across states varies in several ways. First are states in which the method is both legal and available. These include Florida, Illinois, Minnesota, Nevada, North Carolina, Oregon, and Washington. Given the upfront cost of purchasing resomation machines and the uncertainty of customer demand, many states have legalized the process but may not currently offer the service within their borders. These include Alabama, California, Idaho, Kansas, Maryland, Utah, Vermont, and 
Wyoming. Several states have no statutes explicitly approving resomation but allow it by categorizing the procedure alongside fire cremation or the broadly defined language of "other" internment methods. These include Colorado, Georgia, Maine, Michigan, and Missouri. The thirty remaining U.S. states do not allow disposition methods outside of traditional burial (embalmed or natural) and fire cremation. New Hampshire legalized alkaline hydrolysis in 2006, but the law was repealed just two years later and has failed to be re-legalized multiple times since (Atkin 2018a).

The story of alkaline hydrolysis legalization across the United States cannot be told without close attention to the active role of Catholic organizations speaking out against the practice. Certainly, antipathy toward the procedure is not exclusive to Catholicism. American Evangelical groups have expressed skepticism over any form of internment that breaks down the physical body (NAE 2009). Additionally, many Hindu, Sikh, and Buddhist groups frown upon the method due to the centrality of fire cremation in the process of samsara, the cosmic cycle of rebirth and redeath (LaFleur 1992; Mims 2000). An exploration of Catholic statements on alkaline hydrolysis provides a helpful betweencase analysis of fire and liquid cremation debates over the last two centuries.

Shifting religious arguments around the growing practice of fire cremation during the nineteenth and twentieth centuries, discussed above, are particularly illuminating to contemporary resomation debates. Of the U.S. states with the ten highest proportions of Catholic residents, only two legally allow alkaline hydrolysis as a method of internment. Illinois legally recognized the practice in 2012. Like a number of other states with legal resomation, Illinois classified the practice as a method of cremation, more broadly, thus tying its regulation to general crematory policies. The Illinois Crematory Regulation Act, 
a roughly 10,000 word document, only references alkaline hydrolysis once by name in its definition of cremation:

'Cremation' means the technical process, using heat and flame, or alkaline hydrolysis that reduces human remains to bone fragments. The reduction takes place through heat and evaporation or through hydrolysis. Cremation shall include the processing, and may include the pulverization, of the bone fragments. (410 ILCS 18)

California, the second state with a high proportion of Catholic residents that recognizes resomation, passed a law in 2017 legalizing the process. Despite this, there are currently no funeral homes or businesses offering the procedure, as the law only went into effect in the summer of 2020 (Powell 2017). The only other state with a Catholic population comprising at least one-quarter of all residents that legally offers alkaline hydrolysis is Nevada, which passed a revised provisionary document on crematory practices that specifically defined the process in 2017 (A.B. 205 2017). Outside of these few notable exceptions, states with significant Catholic populations have either never taken up the issue of resomation or have rejected attempts to legalize the process. Additionally, states with a smaller proportion of Catholic residents may still hear from local Catholic leadership on the issue.

Echoing earlier positions against fire cremation, the importance of the material body remains the central concern for Catholic leadership (Ernster 2008; Cook 2014; Ruck 2019). Many acknowledge the environmental and financial benefits of resomation relative embalmed burial and cremation but maintain that the perceived disrespect shown to the body through the liquidation and dissolution or soft tissue, along with the pulverizing of 
calcified remains into powder, outweigh any earthly benefit. Arguments against the process on these grounds mirror earlier critiques of fire cremation - i.e. the body is sacred, deserving of respect, and central to the resurrection. Catholic organizations around the United States routinely highlight the need for bodily reverence in their public opposition to the process. When Texas took up a House Bill in 2019 to legalize the process, the Texas Catholic Conference of Bishops released a statement voicing their strong condemnation.

Treating the dead with respect is a duty of the living and a right of the dead and this bill fails to treat the dead with respect. Proponents of alkaline hydrolysis claim that the result is similar to that of cremation with some remains of bones able to be buried. What they fail to explain is that there is also a large volume of liquid, approximately 100 gallons, in which the rest of the body has been dissolved. Usually the liquid is poured into the sewer (Carr Allman 2019).

Reverence for the body is paramount. According to the Texas bishops, all other potential benefits, including the financial benefit of using cheaper internment alternatives, must be secondary:

Respect and reverence for human bodies must not be sacrificed for a cheaper, quicker disposition for medical research facilities. We must treat the remains of all human beings, no matter how long they lived or how they died, with dignity, charity, and respect. Chemical digestion of the human body fails to follow this simple principle (Carr Allman 2019).

Not all Catholic dioceses weigh the environmental impact of alkaline hydrolysis equally. Several official Church statements question the true environmental savings of the process. Missouri's Catholic bishops released a statement in 2018 condemning the process, 
claiming that the environmental impact on local water supplies may negate the reduced $\mathrm{CO} 2$ emissions relative fire cremation.

Some argue that this process is "greener" and more environmentally friendly than traditional cremation, which requires the burning of fossil fuels. However, alkaline hydrolysis results in altering the chemical composition of large amounts of clean water, an increasingly diminishing resource. The environmental impact on the water supply from a large scale use of this process may in practicality offset any purported "green" benefit, not to mention the added strain it would place on municipal water treatment facilities (Missouri Catholic Conference 2018).

Despite common objections, Catholics are not monolithically opposed to resomation. Mirkes (2008) provides an important moral theological challenge to popular Catholic complaints. Notably, he likens the shifting justifications for cremation by the Catholic Church in the 1960s to the contemporary motivations for the greener cremation alternative. Taking detractions in turn, Mirkes suggests little difference between the present acceptance of fire cremation and alkaline hydrolysis. Skeptics who point to the use of alkaline hydrolysis in the decomposition of pets or medical cadavers are reminded of the same uses of fire cremation, as well as the emphasis on personal motivations that were so central to the Papal revisions of 1963. No method of internment, he argues, is intrinsically evil. While bodily burial may still be the preferential method of disposal given the relative worth of human bodies as vessels of immortal souls, alkaline hydrolysis should be considered permissible if Catholics engaging in the practice are able to articulate the importance of the body and resurrection, just as they are asked to do in the case of fire cremation. This argument is echoed by Lasnoski (2016), who champions Mirkes's 
argument as theologically sound and agrees that many critiques of resomation are equally applicable to fire cremation, which is legal and permissible. Still, Lasnoski breaks with Mirkes on the question of Church action, calling on the Church to continue efforts to fight the legalization of the process. While resomation may not be morally distinct from fire cremation, it remains an implicit denial of the doctrine of resurrection.

Like the sanitarians and mid-century cremation advocates before them, resomation proponents face opposition on more than religious grounds. Economic and political stakeholders also have vested interests in the innovation, or the static maintenance, of deathcare options. In many parts of the country, industry professionals have been the driving force behind resomation adoption, evidenced by the Cremation Association of North America's decision to expand their definition of cremation to include alkaline hydrolysis in 2010 (CANA 2019). The first commercial use of alkaline hydrolysis in Ohio, and perhaps the United States, occurred in Columbus at Edwards Funeral Service. Owner Jeff Edwards purchased an alkaline hydrolysis machine in 2010 and quickly began offering the procedure to clients despite no changes explicitly approving the new method of internment. Edwards offered resomation for roughly three months and had carried out nineteen dissolutions before the state ordered him to cease operations (Hunt 2011). The following year, the judge overseeing Edwards's case against the Ohio Department of Health and the Board of Embalmers and Funeral Directors urged the agencies to explore the validity of resomation and its environmental impacts after local water authorities found that Edwards Funeral Service's resomation procedures had not significantly increased alkaline levels in the local water supply (Gilligan 2012). 
The following year, alkaline hydrolysis appeared to be on its way to formal approval through the Ohio statehouse, when a state representative, following consultation with his Catholic priest, removed language approving the procedure from House Bill 481 (Wynn 2013). The representative relayed his discomfort with the resomation process to the Archdiocese of Cincinnati, who released a statement saying reiterating their belief in a bodily resurrection and the need to show reverence through bodily entombment. The issue has not been taken up since 2013 and Ohio still has no formal policy for alkaline hydrolysis. Interestingly, Edwards Funeral Home still offers the procedure. At issue in with the State Department of Health and the Board of Embalmers and Funeral Directors is the legality of bodily disposition - i.e. releasing liquified remains into water supplies. At a significant markup, Edwards Funeral Service carries out the resomation process at their facilities, then transports the remains to Missouri for disposition, where the process is not explicitly regulated, but placed under the umbrella of crematory practices. Packages currently start at $\$ 2000$, but Edwards clarifies that a significant chunk of this cost is associated with the transportation of remains, explaining, "[o]nce [resomation] has been approved in the State of Ohio through legislation, we will then decrease the cost of our aquamation service selections by eliminating travel time and expense to have the actual disposition method performed in the State of Missouri” (Edwards Funeral Service 2021).

Accounting for the inflated transportation costs, aquamation services at Edwards Funeral Home, along with the services offered around the country, still cost well below the national medians of $\$ 9135$ for burial, viewing, and vault and $\$ 5150$ for cremation and viewing (NFDA 2019). Purchasing a resomation machine, as Edwards Funeral Services did, means funeral directors need financial assurances the process will pay for itself over 
time. According to Olsen (2014), the push for Given the potential reductions in revenue, as well as the significant upfront costs to procure an alkaline hydrolysis machine, not all industry experts support alkaline hydrolysis, legalization is not led by grassroots organizing among consumers, but by manufacturers of technology used in the resomation process, illustrating once more the complex web of religious, political, and economic stakeholders that socially construct dominant notions of acceptable internment and memorial. Industries consistently adapt to technological and social change, but these changes are often gradual. Despite its presence in the United States since the early nineteenth century, nothing changed the funeral industry like the rapid ascendance of fire cremation over the last two decades.

Significantly increased rates of cremation have negatively affected multiple deathcare markets from embalming to caskets and vaults, cemetery real estate to headstones. Many practitioners continue to stress the importance of a bodily viewing to the natural processes of grief and healing as a response to these changes, but justifying continued high costs is difficult when cremation is heralded as an economically friendly alternative to established deathcare practices. Additionally, scholars have asserted no significant relationship between the type of mortuary ritual or elaborateness of funeral services and adjustment to the grieving process (Birrell et al 2020). While cremation remains a legal alternative nation-wide, some U.S. states have rejected alkaline hydrolysis for alleged economic self-interest. A 2015 bill would have legalized alkaline hydrolysis in the state of Indiana. Despite confidence in its approval out of committee, the bill was voted down after a sole state representative spoke against it during the general assembly. After vividly describing the pulverization of bone material following fire and liquid cremation, 
he described the process of dissolution as "putting [decedents] in acid and just letting them dissolve away and then we're going to let them run down the drain out into the sewers and whatever" (Cook 2015). While he refrained from arguments on economic grounds, this sole contrarian state representative also owned two large casket companies, but claimed his decision was in no way informed by his personal financial stake in the deathcare industry.

\section{Conclusion}

Despite its first commercial use in 1876, fire cremation was slow to gain national popularity. It would take roughly 140 years for cremation to overtake burial as the preferred internment method in the United States. In that time, a plethora of related deathcare commodities to house or utilize cremains, including elaborate urns, cremain-pressed jewelry, deep sea reliquaries that double as reefs, and tattoo ink that incorporates human ash into memorial tattoos, have established a market for twenty-first century consumption. Once overwhelmingly viewed from afar with suspicion and religious antipathy, cremation is now ubiquitous. Students have no problem drawing comparisons between course lessons on cremation and the numerous people in their lives who elected the process themselves. The naturalization of cremation over the past two decades obscures the lengthy social battle to justify the practice.

Alkaline hydrolysis finds itself at a similar crossroads. Established as a method for disposing animal remains, resomation made its way into human dispossession in the mid2000s, with various U.S. states legalizing or rejecting the process. Currently, 20 states have legalized alkaline hydrolysis with varying levels of access. An exploration of state statutes demonstrates the diverse ways lawmakers categorize and regulate the practice, with some 
following CANA guidelines of regulating alkaline hydrolysis as a method of cremation, and others siding with the NFDA by recognizing the process as a uniquely new form of dispersal set apart from its fire-based alternative. Regardless of state-level classification and availability, critics of the practice have remained steadfast in their religious, political, and economic objections. For the Catholic Church, alkaline hydrolysis represents another defilement of the material body. Despite the liberalization of attitudes regarding fire cremation over the past half century, alkaline hydrolysis currently represents a bridge too far in the alteration and dispossession of human remains. Politically and economically, alkaline hydrolysis may present an existential threat to extant products and services involved in conventional burial methods, including the use of caskets, embalming chemicals, headstones, and cemetery land. Depending on the social, economic, and political capital of industry experts in each state, legalization of alkaline hydrolysis may face stiffer opposition than neighboring jurisdictions.

The first time alkaline hydrolysis is explained in class - the breakdown of soft tissue, the pulverization of calcified bone, and the dispossession of fluid remains - students are shocked, and understandably so. This is a new frontier in deathcare. How states recognize, regulate, or reject alkaline hydrolysis over the next few decades will significantly affect cultural attitudes toward the process. But if the historical battle over fire cremation provides any insight into the contemporary battle over resomation, it is that today's shock may be tomorrow's shrug. 


\section{Ch 4. Dying Responsibly: The Good Death as Neoliberal Individuation}

\section{Introduction}

"Funeral" has become one of the most commonly search "how to plan your own" phrases next to "wedding," "baby shower," and "birthday party." The ascendency of DYI funeral preparation illustrates broad trends in attitudes toward death and dying best described by Walter (1994) as postmodern death. In this articulation, the social context of dying is increasingly placed on the individual subject. The autonomy of decedent's personalized deathcare choices, as well as individualized expressions of grief among the bereaved, decenter community standards and medicalized decision-making. New practices and technologies of death preparedness give rise to the responsible and individuated memorial planner. Ostensibly rejecting familial obligation, several web-based companies warn against the burden of funeral and memorial planning on the part of networks of close friends and family, making it the duty of individuals to make their wishes adequately known prior to death. This extends beyond a cursory, hypothetical discussion with family, demanding detailed plans and methodical attention to detail. Planning leads to peace of mind, both for the deceased and the bereaved. The contemporary deathcare consumer is now empowered to make her own decisions and outline her desires for the "good death." The ever-present specter of untimely death leaves the empowered deathcare consumer also 
exists in a state of continuous vulnerability, making early preparation and vocalization of memorial plans essential.

Adding to the literature on death and dying, this study extends Walter's (1994) topology of death and memorial. However, where other scholars have used his language to explore acts of memorial and bereavement on the part of survivors, this study focuses on the decedent and the role she plays in consuming deathcare resources in preparation for her own death, conceived as both a final act of neoliberal individuation and personal responsibility in the face of perpetual risk. An emphasis on risk is clear in the mission statements of many death preparedness web-companies through continual reminders of untimely death. The specter of illness, or accident, or even malicious violence defines the neoliberal deathcare consumer as always-already dying, therefore always-already in need of preparedness resources. As an emerging digital market, these resources come at a cost, associated with both the amenities reserved for future memorial services and for the maintenance of personalized profiles of memorial plans in company databases. As such, the deathcare consumer, indefinitely at risk of untimely death, is told she has an obligation to plan and maintain accounts in the event of her unavoidable death, occurring decades or mere days from now. Tying these obligations to the consumer market perpetuates social and economic inequality beyond the grave. Social scientists have already highlighted the impacts of deathcare costs in the United States. Annual statistics from the National Funeral Directors Association show that the median cost of a funeral with viewing, burial, and vault in 2021 was $\$ 9,135$, while the median cost of a funeral with viewing and cremation was $\$ 5,150$ (NFDA 2021). 
The means by which individuals navigate this emerging industry may be new, but death has never been, as Susanna Moodie (1989) claimed, “a great equalizer.” Since human groups have conceptualized death as a purposeful process, it has been influenced by social and economic status. In the late twentieth and twenty-first centuries, death and memorialization continue to indicate status, as Mitford (1963) so clearly illustrated in her scathing expose of the American death industry. However, how this status is articulated changes considerably over time. Rituals previously carried out by family and community are now often pre-arranged by the deceased. Rather than seeing these arrangements as articulations of status and power, choices in the neoliberal death industry are framed as extensions of self-identity, individuality, and personal responsibility. As death is one of the few guarantees in life, consumers are always-already dying, and therefore should alwaysalready be in the market for deathcare products. These online companies expose a very real concern in the shifting nature of death and dying in the twenty-first: how to be an informed and empowered consumer of one's own death.

\section{Neoliberal Subjectivity, Biomedicalization, and Deathcare Consumption}

Neoliberalism refers not only to shifting social and economic structures that favor individual liberty and neoclassical economics, but to a "common sense" economization of life that naturalizes a new subjectivity generated through the buying and selling of commodities under capitalism, extending to the totality of human experience (Read 2009). Foucault refers to this new subjectivity as homo economicus - actors primarily driven by competition and financial gain through the economization of life. Importantly, homo economicus is not merely concerned with markets, but becomes a market or "an entrepreneur, and an entrepreneur of himself' (Foucault 2010). While many scholars have 
theorized homo economicus in the realms of health and body image (Biehl 2011), few have explicitly considered the commodification of death, dying, and memorial as a final act of neoliberal subjectivity. The proliferation of web companies specializing in death planning create a market onto which the contemporary deathcare subject "shops" their own deathrites.

According to Dubriwny (2013), this subjectivity is informed by neoliberal understandings of health and wellness as the responsibility of individuals and the consequence of personal choice. The neoliberal rationalization of health policy differs considerably from previous, liberal health policies, through which health intervention was indirect, focused not on the intercession of the state, but rather on who had the ability to speak about medical issues, i.e., professional medical experts (Osborne 1997). Rather than dealing in hands-on, structural, preventative health strategies, the liberal state strived for curative professional interventions, directing the individual to nongovernmental specialists. In contrast, neoliberal health policies offer far more direct and intrusive approaches. According to Osborne, "[n]eo-liberalism abandons the quest for an absolute that would be 'health' and opts for determinant strategies, targets, and specifics instead." In this framework, health is a moving goalpost, requiring continual interventions. Additionally, this neoliberal subjectivity operates within a social context defined by the parallel shift from medicalization to biomedicalization. Peter Conrad (1992) explains medicalization as:

defining a problem in medical terms, using medical language to describe a problem, adopting a medical framework to understand a problem, or using a medical 
intervention to 'treat' it. Medicalization occurs when a medical frame or definition has been applied in an attempt to understand or manage a problem.

Whereas medicalization emphasizes the intrusive potential of external medical agents into heretofore unmedicalized aspects of life, biomedicalization, defined as a micropolitical practice of classifying and regulating bodily processes through postmodern technoscientific advances, places greater importance on the role of the individual in selfregulation and self-surveillance. Through these technoscientific programs, health becomes a commodity and the elusive goal of "well-being" requires continual engagement with the health marketplace. In union with neoliberal health policies, health is reframed as a project and lifestyle. This healthy lifestyle cannot be taken for granted, and the status of "healthy living" is not a fixed objective. Rather, the neoliberal subject is always at risk of being unhealthy. They are, by definition, medically problematic in a society increasingly defined through risk. This neoliberal subject, ostensibly empowered through emphases on personal choice and self-regulation in the biomedical market, is simultaneously at constant risk of being labeled medically problematic and in a perpetual state of vulnerability.

Extending health in life to preparedness in death, new practices and technologies of death preparation give rise to the responsible and individuated memorial planner. The web-based companies discussed below warn against the burden of funeral and memorial planning on the part of networks of close friends and family, making it the obligation of individuals to make their wishes adequately known prior to death. This extends beyond a cursory, hypothetical discussion with family, demanding detailed plans and methodical attention to detail. Planning leads to peace of mind, both for the deceased and the bereaved. Stratified difference in end-of-life planning has already been meaningfully explored (Smith 
et al 2008; Barnato et al 2009; Carr 2012). Concern for the bereaved as vulnerable, themselves, often plays into the necessity of preparedness, as scholars have highlighted with regard to the development of state and federal policies aimed at the deathcare industry (Gentry et al 1995). Conceptualizing the bereaved as susceptible to licentious profiteers adds to the sense of personal responsibility on the part of the deathcare consumer.

\section{Topologies of Death and Grief: Postmodern Death and the Neoliberal Subject}

Walter (1994) describes the three archetypal forms of death as traditional, modern, and neo-modern (elsewhere called postmodern death). Each articulation is informed by corresponding bodily context, social context, and authority surrounding death. These ideal types represent shifts in coping strategies of the bereaved, as well as the values assigned to the death and memorial process. In his analysis, death rites around the world through most of human history fall under the rubric of traditional death. In this form of death and bereavement, local communities inform the social context of dying, which is frequent and typically unexpected or quick. Following the death of a community member, family and friends personally care for the body and prepare funerary rituals, with the aid of religious authority. Lower median ages of death result in a reverence for elders and their veneration upon expiration. Perhaps most importantly, death and bereavement as communal acts place a greater (in some cases total) emphasis on public acts of mourning. Funerals and cremations function as a ritual equally for the dead and the living, reaffirming communal bonds and lineage.

Conversely, modern death is characterized by privatization. Rituals and responsibilities that were previously held by family and friends are now subject to expert systems, including a workforce specializing in various aspects of deathcare. Virtually every 
aspect of post-death preparation is handled by these experts. Death tends to happen in a hospital or in the home with the help of a hospice care company. Immediately following death, the body is taken out of view. In the case of a hospital, it is discretely transported to an off-limits, on sight morgue, where it awaits the arrival of a funeral home director or employee. In the case of a death in the home, the specialist arrives at a private residence and transfers the body to a funeral home where the body is prepared for viewing. The body, now prepared with makeup and clothing, awaits a visitation and funeral, likewise overseen by multiple private entities, including the funeral home, flower companies, specialized memorial agencies, etc. It is only during the designated visitation, funeral, and procession to the cemetery that family and friends interact with the deathcare process. This is a chance for those close to the deceased to make declarations of loss to the broader community and reaffirm lineal and communal bonds. Once final words have been said, onlookers depart from the open gravesite, which is then populated by cemetery maintenance crews and employees from various local vault and headstone companies. In modern death, even annual or semi-annual grave upkeep is optional, as these duties are also performed by specialized labor. According to Walter, the process of death and funeral preparation has left the realm of religious authority, relaying almost exclusively on medical expertise. The body becomes an object, not of religious consideration, but of medical intercession. The corpse now carries the potential for pollution, making it dangerous, not in a supernatural sense, but a medically contagious one.

Likewise, grief and bereavement in modern death is a largely private affair, only occurring publically at specific times and contexts. Outward displays of grief are afforded less and less time and space, as month or even yearlong memorial rituals give way to 
incredibly conservative bereavement policies held by many Western corporations. Short allowances for leave, as well as the precarious employment statuses of hourly or contingent labor, often makes travel to funeral services or subsequent remembrance gathering impossible (Cann 2014). In this arrangement, grief should be private and of short duration. Emphasis is placed on "getting back to normal" and grief is viewed as something to "overcome."

The pressures to hide or ignore public grief and mourning echoes Giddens' (1991) explanation of the sequestration of experience in modernity. Modernity, according to Giddens, is a self-reflexive project characterized by the replacement of externally referential social structures for similar internal referents. The process of rejecting externality includes a de-emphasis on place through disembedding mechanisms. Whereas funerary and memorial practices had previously centered on a fixed ancestral hall, family mausoleum, or community cemetery plot, i.e. traditional death, younger generations increasingly find themselves removed from familial localities and placed in large, urban metropolises devoid of structural resources to support filial obligations to the dead.

Prior to the modern shift, sickness and death were largely public matters regulated through communal ritual. As Giddens points out, it is not until the hospital, forerunner to the modern prison and asylum, separated itself from organizations designed to combat "the poor problem" that ailment became increasingly hidden from public view. The common practice of dying in one's home, surrounded by family and friends was replaced by solitary deterioration in the sterile confines of the modern medical center. As illness, death, and dying receded from public view, the ability to cope with and accept death were similarly deteriorated. Building from the sequestration of sickness and death described by Giddens, 
Mellor and Shilling point to several factors expediting the privatization of death in high modernity, including the re-ordering of biographical narratives in the construction of selfidentity, increased identification of self with body, and a decreasing availability of religious meanings and ritual structures (Mellor 1992). This shifting authority further supports Walter's topology.

Changing modes of death, memorial rituals, and bereavement facilitate new forms of remembrance in what Walter calls postmodern or neo-modern death. Death and the mechanisms by which it is handled remain privatized, but new expressions of mourning allow for public displays of loss. Most importantly, individuality becomes the overriding concern. Now the wishes of the dying individual are made central to the funeral arrangement process. As average life expectancy increasing, the ability to anticipate death and make arrangements oneself are normalized. As such, decisions regarding burial or cremation, vault size and type, and headstone design are made well in advance of sickness or the threat of death. As these decisions have shifted from community and family to the individual, the act of spreading ashes out to sea or being buried in a specific cemetery are now viewed as extensions of self-identity and the consumption of products accentuating the corpse as acts of self-identification.

Post-modern death also extends to the mourning practices of the bereaved. Grief is now made public but is not communal in orientation. Rather, public displays of grief are highly individualized and, as with the deathcare decisions made by individuals in anticipation of their own deaths, viewed as extensions of self-identity. Cann outlined several prominent forms of post-modern grief, including memorial tattoos, car decals, clothing bearing images of the deceased, and internet memorials on various social media 
sites including MySpace and Facebook. Cann theorizes these new expressions of grief are the results of the sequestration of experience in modern death. Corporate bereavement policies and increasing interstate and global migration simply do not make it possible to engage in prolonged, communal, embedded rituals of mourning. Tattoos and online memorials address the growing emphasis on the dis-located, or what she also calls the bodiless body (Cann 2014). For much of the history of purposeful internment, death and mourning centered on the physical remains of the deceased, with communities largely set up around familial gravesites and ancestral halls. However, increased migration through urbanization and globalization have led to alternative methods of mourning absent the physical body. The corpse has become dis-embodied, and acts of remembrance easily transportable. Two key dimensions of individualized death and grief are central to this articulation of deathcare: the decisions of individuals to determine their own internment processes and public, individualized expressions of private grief by the bereaved.

Postmodern death is most helpful when theorized in the context of the neoliberal subject. Both the decedent and the bereaved become informed consumers of their own loss and grief; homo economicus in death as in life. The choices one makes about their own deathcare are not presented as vain expressions of self-identity, but rather as both taking charge of one's own fate and relieving family members of the burden of arranging memorial services in a time of intense sadness. The neoliberal subject, therefore, views the consumption of deathcare as an obligation, and her role as a consumer a selfless act of unburdening loved ones. The funerary rituals, as an extension of the deceased's individuality, now cease to provide acceptable mechanisms for grief when coupled with neoliberal corporate policies for bereavement leave, or lack thereof. These new tensions 
give rise to personalized, consumption-driving mourning practices focused on democratizing loss and highlighting individualized coping strategies through the public display of private memorials (Cann 2014).

\section{Web Companies and Themes}

Planning for one's own death is a big business. Online sites aiding this planning process have proliferated since the turn of the millennium and hit a fever pitch in 2020 during the COVID-19 pandemic (Miller 2020). Even the Federal Trade Commission offers advice for planning your own funeral and subsequent memorial activities (Federal Trade Commission 2012). The promulgation of preparedness services is ostensibly marketed as services to empower individuals to make their own decisions for how best to be memorialized.

A content analysis of the most popular online resources in deathcare planning highlight several common themes. Data collection occurred in the spring of 2018 and the fall of 2020. Companies were selected through web searches of the most prominent death planning options. When necessary, memberships were obtained to access content sequestered from public view. Since the focus of this study is the articulation of a new deathcare subjectivity and its promulgation to the general public, it was determined that premium access to these sites was unnecessary. Additionally, an investigation of premium perks revealed little that would be significant to this study, focused instead on increased data storage and planning resources rather than unique messaging.

A second round of data collection was essential given the growing interest in death planning in recent years, particularly among millennials (Cummins 2020). This steady growth of popularity exploded as the COVID-19 pandemic raged across the globe, making 
major death-preparedness companies, including Cake and Lantern, known commodities in ways not anticipated when this study was conceived (Miller 2020). Although death planning specifically motivated by COVID-19 is not a focus on this study, the context of a global pandemic and the cross-generational risk it produces is an important consideration that cannot be ignored.

MyWonderfulLife.com allows users to create profiles containing their various desires for personalized funeral arrangements. The company, which was featured on an episode of ABC's Shark Tank, was created shortly after the untimely death of a cofounders' spouse in 2006. The co-founders, Sue Kruskopf and Nancy Bush, convinced the latter's husband did not have time to clearly articulate his funeral wishes, developed their web company as a resource for others. On this site, users can designate what they would like to happen with their remains, the type of services that should following their deaths (graveside, funeral home, etc), and many other specific arrangements. "It's a place where you can leave your wishes for your funeral along with any other important information your family will need to know" (About My Wonderful Life 2019).

Founded in 2012, EverPlans.com offers a more diverse array of end-of-life planning, including resources for navigating insurance policies, creating wills or trusts, completing advance directives or DNR (do not resuscitate) forms, and financial planning for a family in the event of an untimely death. Planning one's own funeral arrangements is only one aspect of the web company.

The whole point of our site is to make sure your family, friends and loved ones can manage all the stuff you leave behind. From serious aspects like 'Where is your Will and Life Insurance Policy?' and 'Do you want to be Buried or Cremated' to 
smaller bits that will help ease the burden like 'Where do you keep your Social Security Card' and 'What's the name and number of the cleaning service?' (How to Create Your Everplan 2019).

That death preparation taps into the already lucrative business of event planning is evidenced by the company's origin story. As Abby Schneiderman, one of the co-founders, explains, the idea for a death preparation company developed while planning her own wedding. "As I was being guided through these very happy life changes, I wondered: What resources are there for the 'unhappy' life events? What exists to hold people's hands through death and dying?" (Our Story 2019). Another interesting component of the Everplans website is a detailed directory of health, legal, and end-of-life resources for each state. These resources include information on state-by-state legislation pertaining to organ donation, DNR forms, advance directives, digital estate planning, and the process of procuring death certificates.

Funeralwise.com was initially founded in the 1990s by Richard Paskin and Larry Anspach. According to Paskin, the web company "was way ahead of its time and after a few struggling years we decided to put the site on hold" (Who are the Funeralwise Wiseguys 2019). It reemerged in the 2000s and is now one of the premier death preparedness web companies. According to the company, their mission is to help individuals and families navigate the deathcare industry, both in preplanning one's own funeral and arranging the deathrites of deceased family and friends. The comprehensive site contains resources for funeral and disposal planning, proper funeral etiquette, navigating grief, finding deathcare providers, and how to care for recently deceased pets. 
Finally, Cake and Lantern are two companies founded in 2015 and 2018, respectively. Despite their pre-pandemic origins, these companies represent the biggest growth in a COVID-19 world. Interestingly, their public-facing biographies and content presentation reflect the taken-for-granted necessity of memorial planning since the spring of 2020. Each provide robust databases of deathcare resources while placing far less emphasis on the novelty of internment and memorial planning. A unique aspect of these two companies is their deathcare blogs, which feature articles from industry experts, academics, and customers on topics ranging from the benefits of preplanning to strategies for discussing death and creating a will with elderly family. This provided a wealth of data for the relevant themes discussed below.

\section{Theme 1: Memorial as the Final Act of Individuation}

The importance of personal choice and control are the most central driving forces behind the planning process. As a 2014 New York Times article states,

Although death planning may be one of the most difficult things you will do, it is one final act of self-determination. You may not have control over your last minutes on earth or how you will be remembered, but you can certainly guide your survivors on how you want to be treated and memorialized (Wasik 2014).

Potential customers are routinely reminded that failing to make their wishes known to family and friends could have dire consequences for their memorial services. Emphasis on individual preference illustrates the extension self-identity in postmodern death. How the subject is remembered and celebrated - if the subject chooses to be remembered and celebrated at all - may be the last and most crucial act of individuation. Second, planning one's death is consistently framed as a responsibility of the individual. 
The lasting image of the deceased is a central concern expressed by these companies. Individual preference is characterized as a direct representation of character. My Wonderful Life offers numerous reasons potential customers, even those of relatively good health, should care about this decision-making process. "For all but your closest friends and family, your funeral or memorial service will dominate your legacy [emphasis mine]" (Why Bother? 2012). In death, we will be judged, if not by an omniscient being, then by our peers. Yet again illustrating the importance of individual choice and control, the company goes on to state that the process of planning one's own death gives the planner the "last word." The planning process allows the deceased to dictate, as much as possible, the terms by which they are remembered and mourned. Everplans is also explicit about the benefits of leaving a detailed death plan for loved ones. "By planning your service in advance you can design and specify the exact type of service you'd like, so that your friends and family celebrate you as you wish [emphasis mine]" (Funeral Pre-Planning Cheat Sheet 2019). This ability to have a final say in the celebration of your life is echoed by Funeralwise. "A funeral is the ultimate celebration of your life. Planning ahead will give you the opportunity to decide what you want, how you want it, and when you want it" (Funeral Planning 2019). This emphasis on individual preference supports postmodern deathcare's focus on the desires of the individual over family or the broader community. As a more comprehensive web-company, Everplans offers far more suggestions for personalization and control. Among the questions on the website, Everplans asks potential clients to decide where they would like services to be held, where to be buried and how to pick the best cemetery, who should officiate a memorial service, which family or friends should be designated pallbearers, who should give eulogies or prayers, and even who 
should be invited to the wake or funeral service (How to Pre-Plan Your Funeral 2019). As the ultimate and final act of individuation and self-identity, the funeral now acts as an exclusive event with a limited guest list. Lantern echoes the risk of bereaved family and friends mistaking the final wishes of the deceased, warning "planning ahead after major life changes - both the happy and sad ones — is crucial to ensuring your loved ones know how to handle the treasures and memories you will one day leave behind" (Selby 2020). Decisions that were previously left to the community, and which functioned to reinvigorate familial and communal bonds, eg. designating pallbearers or participants in other important memorial rituals, are now pre-determined by the deceased on a micro-level. As the final, ultimate act of individuation, customers do not want to leave their wishes to chance or poor execution. As Funeralwise asks, "[w]hy leave the ultimate celebration of your life to the last minute" (Plan a Funeral in Advance 2019)?

\section{Theme 2: Personal Responsibility and Mercy}

The Federal Trade Commission advises early planning that "spares your survivors the stress of making these decisions under the pressure of time and strong emotions. You can make arrangements directly with a funeral establishment. [emphasis mine]" (Federal Trade Commission 2012). Neglecting even the most innocuous details of one's death and funeral creates an undue burden on family and friends. As the tagline of a popular website, OkToDie.com, states, "it is ok to die... when you are prepared." Dying without explicitly making memorial decisions is framed as irresponsible and burdensome to loved ones. Preparedness and clarification of memorial instructions is akin to the good death, described by OkToDie.com as a "peace-filled end of life." 
Managing the minute details of one's own funeral and internment may seem vain or self-serving, but many companies explicitly reframe the self-management of these important ritual acts as selfless and merciful. Time and again, the need to plan deathcare, from major decisions regarding disposal of the body to the minor details of flower arrangements and service times, is framed as an act of personal responsibility for the decedent and mitigation of additional stress and grief for the future bereaved. My Wonderful Life repeatedly stresses the emotional devastation of death on surviving family and friends. Ambiguous or nonexistent memorial plans only adds to this pain, creating more confusion for already-exhausted mourners.

Along with grief, a loved one's death can spawn a massive to-do list. Between meetings with lawyers, funeral directors and financial advisors, bereaved survivors are often left to wonder 'Is this what they would have wanted?' when it comes to a memorial. Planning your own final send-off takes the guesswork (and the burden of decision-making) out of the equation (Why Bother? 2012).

The website also allows users to assign friends and family to the Angel Boot Camp. "Angels" are those individuals specifically tasked with making sure the deceased's wishes are carried out properly. According to the website, "[b]eing an Angel for a loved one will take away some of the stress family and friends feel after a loved one passes away. It eliminates the guesswork, because you'll know what they wanted [emphasis mine]" (Angel Boot Camp 2012). In this sense, proper articulation of deathcare preferences are the responsibility of both the deceased and whomever they designate as angels. In both cases, adherence to the wishes of the deceased is framed as a duty. Failure to carry out these wishes exacerbates the grief and confusion of an already distraught network of close family 
and friends. Though the wishes of the individual are still central to this process, the job of carrying out these plans is now shared by previously designated death plan aids. Everplans also frames the need to plan memorial arrangements in the context of survivor grief. "[B]y letting your family know how you'd like your funeral or memorial service to be, they'll have less difficult and complicated decisions to make during a difficult emotional time" (Pre-Planning Funeral Cheat Sheet 2019). The repetition of the adjective "difficult" is important here. The loss of a loved one creates difficulty (i.e., sadness, confusion, and pain). Planning memorial services is likewise sad, confusing, and painful. One of these sources of grief can be alleviated through careful planning on the part of the deceased. Like My Wonderful Life's angels, Everplans also allows customers to designate "trusted deputies" to carry out their wishes.

Other sites further equate preplanning with mercy and a concern for survivors' grief. "Taking care of your funeral arrangements is a thoughtful and caring thing to do for your family. It is comforting to know that you have done all you can do to ease their burden. And you can be assured that they will appreciate that your caring for them continued after you are gone" (Plan a Funeral in Advance 2021). A primary concern for any person reflecting on their eventual death is the safety and security of their loved ones. Lantern likens the concern for family and proactive decision to preplan as the best way to illustrate love for family (Ruderman 2021). By positing the preplanning of death arrangements as an extension of care beyond the grave, companies taps into this uncertainty and rearticulates it as personal autonomy. An oncology social worker on the "Cake Blog" similarly describes preplanning as "a gift to your family" in the event of an emergency (MacDougall 2020). Likening the good death to personal responsibility in deathcare planning echoes the 
individual subjectivity cultivated through neoliberal ideology, one who is "subject to increasing discourses of individuation and responsibility" (Dubriwny 2013). Not only is it incumbent upon this subject to make decisions illustrative of individual preferences as an extension of self-identity, but it is also their duty to make sure these arrangements are made well before their own death to save loved ones from the pain and uncertainty of planning themselves.

\section{Theme 3: The Specter of Untimely Death}

The impetus for planning death services is often couched in the language of risk. Despite growing interest in deathcare planning among millennials (Cummins 2020), skeptical clients may ask why they should dwell on their own deaths, which may not happen for years or decades. Many websites admit this point, but emphasize the possibility of untimely death, to which we are all potentially susceptible. Untimely death is discussed in two ways across websites: by explicitly warning healthy and/or young clients of their own risk and by implicitly reminding healthy and/or young clients of risk through narratives of unexpected loss, typically in the retelling of company origins.

First, companies explicitly warn clients of the potential for death at any stage of life. As Ok to Die warns,

If you are reading these words, the day will come when you will die. Usually death comes expectedly, at the end of a long, well-lived life or at the end of a terminal illness. But on occasion, death arrives without warning. Accidents, sudden illness, even becoming the victim of a crime can cause you to die without notice, without time to plan. Don't be caught unprepared (Planning for Your Own Death 2011). 
As the company acknowledges, most will die expectedly with time to plan memorials. However, all are at risk of untimely, perhaps even violent, death. The unplanned, unseen specter of illness and death perfectly illustrate risk as articulated by Castel: "[A] risk does not arise from the presence of particular precise danger embodied in a concrete individual or group. It is the effect of a combination of abstract factors which render more or less probable the occurrence of undesirable modes of behavior" (1991). In this case, the "undesirable mode of behavior" is death, but death is not "more or less probable." It is inevitable. What is at risk is the untimely death brought about by illness or calamity. As such, the neoliberal deathcare consumer is always-already at risk of dying. This makes planning for deaths and memorials even more salient, regardless of good health or age.

As one of the most robust death-preparedness companies, Cake hosts a significant repository of editorials and articles by industry experts, academics, employees, and clients that cover a wide range of deathcare topics. Explicit reminders of risk and untimely death feature prominently. Articles ranging from "10 Reasons You May Be Scared of Death Lately" to "This is What Happens to Student Loan Debt When You Die" center the reality of death for younger readers.

The personal narratives provided by each companies' co-founders further illustrate the potential for untimely death. In the case of My Wonderful Life, Nancy Bush lost her husband to cancer in 2006. "We felt a website like MyWonderfulLife.com would have made it easier for [Bush's husband] to express his personal wishes, and to leave letters and memories for his family left behind" (Our Story 2012). The age of her husband at the time 
of his death, 52, is explicitly mentioned to emphasize that the specter of illness and death hangs over everyone.

Similarly, the Everplans website alludes to personal loss as an impetus for the company's formation. Schneiderman's narrative offers fewer details about her experience. Sometime between 2010 and the founding of Everplans in 2012, she experienced "a devastating tragedy that not only profoundly affected me, but had an impact on the whole Everplans team" (Our Story 2019). This led Schneiderman and co-founder Adam Seifer to develop the Everplans brand beyond online consumer information articles and into the detailed online resource center it is today.

Despite the limitations of modernist conceptions of risk society, as articulated by Petersen (1991), both Beck (1992) and Giddens' (1990) theories of risk provide thoughtful opportunities to investigate these web-based companies. Most importantly, as traditional social structures lose power, the individuated subject increasingly relies on expert systems to organize life. By extension, these same expert systems become progressively necessary in the organization of death. Companies often place the expertise of their staff front and center. The co-founders of Funeralwise, Richard Paskin and Larry Anspach, do not frame their emergence in the deathcare preparedness business as rooted in personal loss. Both men highlight their business backgrounds. While Paskin highlights the many ways he serendipitously became involved in the industry, Anspach heavily emphasizes his four decades of deathcare work. Potential customers are reminded of the specter of death through the biographies of other central Funeralwise employees, who highlight the similar untimely and surprising personal loses as catalysts to their involvement in the deathcare industry. In each case, potential customers are routinely reminded of the possibility of 
death, lending further support to the formation of the neoliberal deathcare consumer in the risk society.

\section{Conclusion: Death, the Final Frontier}

With the advent of online databases for memorial self-preparation, biomedicalization and neoliberal individuation have finally permeated all aspects of life, including death. Utilizing the lens of postmodern deathcare, a growing number of webbased companies provide means by which the social context of death is increasingly placed on the individual, rather than the broader community, family, religious authority, or medical experts.

Theorizing postmodern death in the context of neoliberal subjectivity allows for a thoughtful bridge between the biomedicalized, subject and the homo economicus consumer of online deathcare following the emergence of web-based companies specializing in memorial preparedness. Building off the work of Walter, Cann and others have focused on the role of individuation in postmodern death through explorations of bereavement and memorial among networks of surviving friends and family. This study extends that scholarship with specific attention to the always-already dying individual as a consumer of her own memorial services.

As subscription services with "freemium" content, deathcare websites may reproduce the social and economic inequalities of life in death. Neoliberal subjectivity ignores structural elements to these forms of inequality, instead focusing on decontextualized, individual choice. This choice, the decision to engage in preparatory deathcare services, is marketed as a final act of self-identity and individuation. Perhaps more importantly, utilization of these services is reframed as a responsibility of the 
individual, unburdening family and friends of the need to plan memorial services themselves. Despite the potential to exacerbate inequality, many companies use historically disparate experiences of end-of-life planning and inequalities in achieving the good death as a clarion call to make planning and open communication accessible through free services (Loe 2021).

The goal of this study is not to provide a positive or negative valuation of contemporary death preparedness services. A nuanced examination of these websites, their FAQ pages, and blogs clearly indicate many clients and their families want preplanning and an alleviation of responsibility at the time of death. Removing the obligation of internment preparations immediately following the loss of a loved one may be a welcome relief for many survivors. Future studies could focus on the experiences of clients and families to elucidate this complexity. Additionally, future work should address potential conflict that may arise from disagreements between survivors or the refusal to carry out the wishes of decedents. Unlike wills, trusts, or resuscitation orders, many individuated preferences for memorial and internment are not legally binding. How do families balance the wishes of the deceased with financial limitations and the potential for competing interpretations among stakeholders?

Individuation and personal responsibility define the biomedicalized subject. Likewise, this study sought to define the neoliberal deathcare consumer along these lines. Deathcare preparedness web companies function perfectly within this framework. Although online resources are only now becoming mainstream, it is not outlandish to envision a world in which these and similar services become the expectation. Individuals 
may one day think about planning their own deaths as they think about planning their own weddings or birthdays. Popular Google search results already support this assertion.

\section{Ch 5. Conclusion: Death \& Dying in a Post-Pandemic World}

If public awareness of any topic has changed since I proposed these essays, it is related to the existence of deathcare planning websites. Since the advent of COVID-19, death planning web services have seen a significant rise in traffic (Miller 2020). A global pandemic presents one of the most salient examples of untimely death, leading many to openly discuss the necessity to make deathcare plans. In June of 2020, National Public Radio's Life Kit called end-of-life planning a "lifetime gift" to loved ones, stressing the unnecessary strain of memorial planning on surviving family while bereaved (Cardoza 2020). In many ways, business lockdowns, quarantine, and social distancing guidelines situated web-based end-of-life services perfectly to meet the uniquely new demand brought about by the extreme circumstances. Initial content analyses of death planning websites began in 2017, was revisited in 2019, and then again near the 2021 new year. Several noteworthy web companies had significantly grown in notoriety between the second and third analyses and many extant sites featured new sections dedicated to COVID-19, digital mourning, and untimely death resulting from illness. 
As with many research agendas, COVID-19 undoubtedly altered the landscape of my topic in real time, and my focus would have assuredly been minorly or significantly different had I begun data collection during or after the pandemic. This points to the potential for future work. Specifically, I would be interested in following up with the green burial practitioners who spoke with me roughly two years ago. The handling of the dead was an important concern in the early stages of national lockdown and COVID restrictions, leading many funeral homes to provide remote services with limited or no family gathering.

Cultural shifts in dominant modes of deathcare are often precipitated by major social events that demand adaptation (Seale 1998). In the nineteenth century, the massive number of war dead and the desires of their grieving families to recall their bodies for memorial and internment catalyzed the ubiquity of embalming in the American funeral industry (Laderman 1998; Gilpin Faust 2009). Undertakers would form professional organizations, trading in their stigmatized, dour stereotypes for three-piece suits, business cards, and memberships in professional organizations. At roughly the same time, sanitarians and public health experts responded to urban cholera epidemics by advocating for stringent sanitary reforms to curb the miasmatic transfer of contagion, fundamentally altering many aspects of daily life (Duffy 1990). These calls would lead to a new, industrialized fire reclamation process for safely disposing of human remains. Unlike embalmer-undertakers, cremation advocates of the late nineteenth century had to address serious questions of bodily resurrection. While some cremationists attempted to maintain notions of a literal resurrection, it is during this period a greater emphasis is placed on a spiritual resurrection, citing the Pauline claim that "flesh and blood cannot inherit the Kingdom of God" (Prothero 2001, 84). In this case, we see a socio-religious shift in 
articulations of death, the body, and the afterlife driven by sanitary reforms and public policy, just as wartime demands shifted conceptualizations of the body, decomposition, and memorial. Cremation would remain a highly controversial and niche internment option until the early 1960s, when the unexpected combination of a British-American journalist and the Roman Catholic Church opened the floodgates on the social acceptability of the process. The American Way of Death was a national bestseller, exposing longstanding, nefarious funeral industry practices and generating doubt in deathcare consumers that the industry has had trouble remedying to this day (Robson 2016). That same year, the Second Vatican Council decreed that fire cremation was an acceptable, if still not preferred, method of disposal, removing a near century old religious proscription. These two events are often credited with dampening national hesitancy to embrace the alternative, leading to a gradual shift that culminated in 2015 with the National Funeral Directors Association declaring cremation as the primary method of internment in the United States (NFDA 2019).

We may be living in another flashpoint in the American funeral industry. Consumer demands have led to innovation and change across various sectors of deathcare (Beard \& Burger 2017). Germinating frustration from the days of Jessica Mitford, coupled with environmental critiques of embalming and fire reclamation, drove natural and green burial initiatives in the United Kingdom and later the United States, creating a small but growing niche industry across all fifty states. Many of the most noteworthy changes of the last two decades have been motivated by a mix of environmental and economic concerns. Natural organic reduction, a method of breaking down the body in a natural mix of brown and green matter for use in gardens also known as human composting, was officially legalized in Washington state in 2019. In December of 2020, Recompose, the first natural organic 
reduction facility in the United States, began the composting process on the first set of human remains (Kiley 2021). In March of 2021, HB2574 was introduced to the Oregon state legislature (Ray Lambert 2021). If passed, Oregon will become the second state to legalize natural organic reduction for human bodies. I will continue to watch these legislative developments with a keen interest in how the emergence of this industry mirrors or diverges from the parallel battle over alkaline hydrolysis.

Cultural shifts in deathcare acceptance do not only manifest in opinion polling or industry statistics on consumer behavior. Often, the development of new technologies brings with it a complicated nexus of legal, religious, and economic reclassifications in extant or emerging typologies of internment. There is no federal uniformity in resomation policy. Among the twenty states with legal or laissez faire resomation policies, there is an inconsistency in the categorization of the practice. For some, alkaline hydrolysis is simply a new iteration of cremation, making it subject to the same laws and regulations. This categorization is supported by major deathcare organizations including the Cremation Association of North America (CANA). Other states, following the guidance of the NFDA, recognize resomation as a new and distinct form of internment, writing unique regulations specific to the process. These categorizations matter. Much contestation surrounding the approval or rejection of alkaline hydrolysis is heavily contingent on how religious authorities, politicians, industry experts, and the public conceptualize the process (Olsen 2014).

Adding to an already shifting landscape in deathcare options, COVID-19 may represent its own inflection point in consumer behavior, decedent priorities, and twentyfirst century articulations of the good death. Death in the twenty-first century United States 
is already characterized by briefness and efficiency under capitalism, and spatial limitations brought about by increased domestic and transnational migration (Cann 2004). Beginning in the spring of 2020, spatial limitations became a concern even for those geographically proximate their deceased family and friends. Guidelines published by health and virology organizations around the world represented new "cosmologistical problems" (Vasquez \& Friedmann Marquardt 2003) for mourners driven by concerns for a good death articulated through religio-cultural scripts. March 2020 World Health Organization (WHO) guidelines outlined numerous directives for medical staff, deathcare practitioners, and family regarding the handling, transportation, and viewing of decedents. In the early days of the global pandemic, much was still unknown about the transmission of COVID-19. Early studies stressed the potential risk of viral spread due to the handling of bodies of confirmed or suspected COVID-19 victims (Rani 2020). Many of the guidelines outlined by WHO were echoed by the Centers for Disease Control (CDC), the Public Health Agency of Canada, and other national disease centers. While most of these organizations agreed on the necessity of social distancing and limiting gatherings to a small number of intimate mourners, there were notable differences in approach to family interaction and ritual decorum. WHO advised against embalming to mitigate practitionerinteraction with the corpse. Additionally, they advised practitioners to bar family and friends from physically interacting with the dead. "If the family wishes only to view the body and not touch it, they may do so, using standard precautions at all times including hand hygiene. Give the family clear instructions not to touch or kiss the body" (WHO 2020). In contrast, the CDC has stated its opposition to the WHO's guidance on embalming and funeral services, instead stressing the need for social distancing and small gatherings. 
Physical proximity to and interaction with the deceased is an important component of many piacular rituals. Future work should explore religious tensions precipitated by the sequestration of decedents during pandemic guidance.

The digitization of memorial in 2020 was not wholly negative. For some, digital alternatives to the funeral home provided new means to solve extant spatial memorial dilemmas. Prior to lockdown, many funeral homes only offered service livestreams and digital recordings as an optional, and typically costly, service. Now, thousands of funeral homes around the United States provide virtual options. Not only does this mitigate the spread of the coronavirus, but also allows bereaved who otherwise could not travel for services to "attend" in real time. Of course, for others, Zoom services and Facetime condolences create new problems and a sense of not living up to the expectations of ars moriendi. Time will tell if any processes or services developed to meet the specific needs of memorial during a global pandemic remain operative as we slowly march toward some semblance of pre-COVID normalcy.

One of the primary obstacles to thinking sociologically is the reductionist tendency to analyze the world through an individualist lens (Mills 1959; Desmond \& Emirbayer 2009). Nowhere is this tendency greater than in relation to loss, grief, and memorial. The death of a loved one is deeply personal and contemplating our own mortality incredibly isolating. This may be why I gravitate to sociological analyses of death and dying. Socialization within the complex webs of institutional forces does not stop at the funeral parlor, green burial forest, or crematorium. How we grieve, why we grieve, and how we respond to the process of dying and decedents are deeply social processes. Sociology is ideally situated to engage religio-cultural scripts and their interactions with political, 
economic, and social currents in the maintenance, reproduction, and rearticulation of deathcare. Conceptualizations of ars moriendi, along with a sense of its achievement or failure, are socially mediated. While psychological and medical examinations of the good death provide valuable insights, they are limited in their analytic scope. These investigations point to the future contributions of sociology in weighing the question of what it means to die well.

\section{Bibliography}

Aries, Phillipe. 1974. Western Attitudes Toward Death: From the Middle Ages to the Present. Baltimore: Johns Hopkins University.

Atkin, Emily. 2018a. "The Fight for the Right to Be Cremated by Water." The New Republic. Retrieved from https://newrepublic.com/article/148997/fight-rightcremated-water-rise-alkaline-hydrolysis-america

Atkin, Emily. 2018b. "The Powerful Groups Stonewalling a Greener Way to Die." Wired. Retrieved by https://www.wired.com/story/the-powerful-groupsstonewalling-the-greener-way-to-die/

Audebrand, Luc K. and Marcos Barros. 2017. "All Equal in Death? Fighting Inequality in the Contemporary Funeral Industry.” Organizational Studies. 39(9): 1323-1343.

Banks, Dwayne A. 1998. "The Economics of Death: A Descriptive Study of the Impact of Funeral and Cremation Costs on U.S. Households.” Death Studies. 22(3): 269285.

Barnato, Amber E., Denise L Anthony, Jonathan Skinner, and Patricia M. Gallagher. 2008. "Racial and Ethnic Differences in Preferences for End-of-Life Treatment." Journal of General Internal Medicine. 24(6): 695-701.

Beard, Virginia C. and William C. Burger. 2017. "Change and Innovation in the Funeral Industry: A Typology of Motivations.” OMEGA - Journal of Death and Dying. 75(1): 47-68.

Bell, Catherine. 1992. Ritual Theory, Ritual Practice. Oxford: Oxford University Press.

Biehl, João. 2011. “'Homo Economicus' and Life Markets.” Medical Anthropology Quarterly. 25(2): 278-284.

Biernacki, Patrick and Dan Waldorf. 1981. "Snowball Sampling: Problems and 
Techniques of Chain Referral Sampling." Sociological Methods \& Research. 10(2): 141-163.

Birrell, John, Henk Schut, Margaret Stroebe, Daniel Anadria, Cate Newsom, Kate Woodthorpe, Hannah Rumble, Anne Corden, and Yvette Smith. 2020. "Cremation and Grief: Are Ways of Commemorating the Dead Related to Adjustment Over Time?" OMEGA—Journal of Death and Dying. 81(3): 370-392.

Bouverette, A.A. 2017. "Green Burials: The Deinstitutionalization of Death." The Hilltop Review. 10(1): 48-56.

Breschi, Marco. 2018. “'Ashes to Ashes...': Could the Recent Evolution of the Cremation Practice in Italy be Interpreted as an Indication of Secularisation?" Review of Religious Research. 60(4): 519-533.

Buchanan, Tom and Paige Gabriel. 2015. "Race Differences in Acceptance of Cremation: Religion, Durkheim, and Death in the African American Community." Social Compass. 62(1): 22-42.

CANA. 2019. "Alkaline Hydrolysis." Cremation Association of North America. Retrieved from https://www.cremationassociation.org/page/alkalinehydrolysis

Cann, Candi K. 2014. Virtual Afterlives: Grieving the Dead in the Twenty-First Century. Lexington: University Press of Kentucky.

Caralis, P. V., Davis, Bobbi, Wright, Karen, \& Eileen Marcial. 1993. "The Influence of Ethnicity and Race on Attitudes Toward Advance Directives, Life-Prolonging Treatments, and Euthanasia." Journal of Clinical Ethics. 4(2): 155-165.

Cardoza, Kavitha. 2020. "End-of-Life Planning is a 'Lifetime Gift' to Your Loved Ones." NPR: Life Kit. Retrieved from https://www.npr.org/2020/06/26/884051182/endof-life-planning-is-a-lifetime-gift-to-your-loved-ones

Carr Allman, Jennifer. 2019. Testimony regarding HB 773: No Aqua Cremation of Human Remains. Texas Catholic Conference of Bishops. Retrieved from https://txcatholic.org/hb-773-no-aqua-cremation-of-human-remains/

Carr, Deborah. 2003. “The 'Good Death' for Whom? Quality of Spouse's Death and Psychological Distress among Older Widowed Persons." Journal of Health and Social Behavior. 44(2): 215-232.

Carr, Deborah. 2011. "Racial Differences in End of Life Planning: Why Don't Blacks and Latinos Prepare for the Inevitable?" OMEGA: Journal of Death and Dying. 63(1): 1-20.

Carr, Deborah. 2012. "Racial and Ethnic Differences in Advance Care Planning: 
Identifying Subgroup Patterns and Obstacles." Journal of Aging and Health. 24(6): 923-947.

Carr, Deborah. 2012. "The Social Stratification of Older Adults' Preparations for End-ofLife Health Care." Journal of Health and Social Behavior. 53(3): 297-312.

Carr, Deborah. 2016. "Is Death 'the Great Equalizer'? Social Stratification of Death Quality in the United States." The Annals of the American Academy. 663: 331354.

Castel, Robert. 1991. "From Dangerousness to Risk." In The Foucault Effect: Studies in Governmentality. Burchel, Graham, Colin Gordon, and Peter Miller eds. Chicago: The University of Chicago Press.

Clayden, Andrew and Katie Dixon. 2007. "Woodland Burial: Memorial Arboretum Versus Natural Native Woodland?” Mortality. 12(3): 240-260.

Colombo, Asher J. 2017. "Why Europe has Never Been United (Not Even in the Afterworld): The Fall and Rise of Cremation in Cities (1876-1939)." Death Studies. 41(1): 22-33.

Conrad, Peter. 1992. "Medicalization and Social Control." Annual Review of Sociology. 18: 209-232.

Cook, Meredith P. 2014. Testimony Regarding HB1577 Regulating Alkaline Hydrolysis. Diocese of Manchester Secretariat for Administration.

Cook, Tony. 2015. "Casket-Marking Lawmaker Helps Kill Bill Allowing Alternative to Burial." Indy Star. Retrieved from https://www.indystar.com/story/news/ politics/2015/03/20/casket-making-lawmaker-helps-kill-bill-allowing-alternativeburial/25109443/

Coutts, Christopher, Carlton Basmajian, Joseph Sehee, Sarah Kelty, and Patrice C. Williams. 2018. "Natural Burial as a Land Conservation Tool in the US." Landscape and Urban Planning. 178: 130-143.

Cummins, Eleanor. 2020. "Why Millennials are the "Death Positive" Generation." Vox. Retrieved from https://www.vox.com/the-highlight/2020/1/15/21059189/deathmillennials-funeral-planning-cremation-green-positive

Cutler, David and Grant Miller. 2005. "The Role of Public Health Improvements in Health Advances: The Twentieth-Century United States." Demography. 42(1): 122.

Davies, Douglas J. 1996. “The Sacred Crematorium.” Mortality. 1(1): 83-94. 
Davies, Douglas J. 2015. Mors Britannica: Lifestyle and Death-Style in Britain Today. Oxford: Oxford University Press.

De Spiegeleer, Christoph. 2019. "Secularization and the Modern History of Funerary Culture in Europe Conflict and Market Competition Around Death, Burial and Cremation." Trajecta: Religion, Culture and Society in the Low Countries. 28(2): 169-201.

Douglas, Mary. 1978. Purity and Danger: An Analysis of the Concepts of Pollution and Taboo. London: Routledge \& Kegan Paul.

Dubriwny, Tasha N. 2013. The Vulnerable Empowered Woman: Feminism, Postfeminism, and Women's Health. New Brunswick: Rutgers University Press.

Duffy, John. 1990. The Sanitarians: A History of American Public Health. Urbana: University of Illinois Press.

Durkheim, Emile. 2008. The Elementary Forms of Religious Life. Carol Cosman trans. Oxford: Oxford University Press.

Edwards Funeral Service. 2021. "Aquamation Packages: Pioneering Green Solutions.” $C F S \& T A$. Retrieved from https://www.edwardsfuneralservice.com/aquamationpackages

Ernster, Barb. 2008. “Chemical Cremation.” National Catholic Register. Retrieved from https://www.ncregister.com/news/chemical-cremation

Everplans. 2016. New York: Beyondly, Inc. Retrieved August 15, 2019. https://www.everplans.com.

Federal Trade Commission. 2012. "Consumer Information - Planning Your Own Funeral.” Retrieved December 6, 2016. https://www.consumer.ftc.gov/ articles/0305-planning-your-own-funeral.

Foucault, Michel. 1980. Power/Knowledge: Selected Interviews \& Other Writings 19721977. Colin Gordon (ed). New York: Pantheon Books.

Foucault, Michel. 2010. The Birth of Biopolitics: Lectures at the College de France, 1978-1979. Graham Burchell, trans. New York: Picador

Funeralwise. 2019. Wilmette: Funeralwise, LLC. Retrieved August 15, 2019. (https://www.funeralwise.com)

Garces-Foley, Kathleen and Justin S. Holcomb. 2006. "Contemporary American Funerals: Personalizing Tradition." In Death and Religion in a Changing World, Kathleen Garces-Foley ed. Armonk, NY: M.E. Sharpe. 
GBC. 2020. "Our Standards.” Green Burial Council. Retrieved from https://www.greenburialcouncil.org/our_standards.html

Gentry, James W., Patricia F. Kennedy, Katherine Paul, and Ronald Paul Hill. 1995.

"The Vulnerability of Those Grieving the Death of a Loved One: Implications for Public Policy.” Journal of Public Policy \& Marketing. 14(1): 128-142.

Giddens, Anthony. 1990. The Consequences of Modernity. Cambridge: Polity Press.

Giddens, Anthony. 1991. Modernity and Self-Identity: Self and Society in the Late Modern Age. Cambridge, UK: Polity Press.

Gilpin Faust, Drew. 2008. This Republic of Suffering: Death and the American Civil War. New York: Vintage Publishing.

Glaser, Barney G. 1965. "The Constant Comparative Method of Qualitative Analysis." Social Problems. 12: 436-445.

Glass, Anne P. and Linda F. Samuel. 2011. "A Comparison of Attitudes about Cremation among Black and White Middle-Aged and Older Adults." Journal of Gerontological Social Work. 54(4): 372-389.

Gwenzi, Willis. 2021. "Autopsy, Thanatopraxy, Cemeteries and Crematoria as Hotspots of Toxic Organic Contaminants in the Funeral Industry Continuum." Science of the Total Environment. 753: 1-20.

Harrington, David E. and Kathy J. Krynski. 2002. "The Effects of State Funeral Regulations on Cremation Rates: Testing for Demand Inducement in Funeral Markets." Journal of Law and Economics. 45: 199-225.

Harris, Mark. 2007. Grave Matters: A Journey through the Modern Funeral Industry to a Natural Way of Burial. New York: Scribner.

Hart, Bethne, Peter Sainsbury, and Stephanie Short. 1998. "Whose Dying? A Sociological Critique of the 'Good Death."' Mortality. 3(1): 65-77.

Hockey, Jenny, Trish Green, Andy Clayden, and Mark Powell. 2012. "Landscapes of the Dead? Natural Burial and the Materialization of Absence." Journal of Material Culture. 17(2):115-132.

Holy See Press Office. 2016. "Instruction Ad Resurgendum cum Christo Regarding the Burial of the Deceased and the Conservation of the Ashes in the Case of Cremation, 25.10.2016." Summary of Bulletin. Retrieved from https://press.vatican.va/content/salastampa/en/bollettino/pubblico/016/10/25/1610 $25 \mathrm{c} . \mathrm{html}$ 
Howard, Glennys. 2005. "Whatever Happened to Social Class? An Examination of the Neglect of Working Class Cultures in the Sociology of Death." Health Sociology Review. 16: 425-435.

Hsieh, Hsiu-Fang and Sarah E. Shannon. 2005. "Three Approaches to Qualitative Content Analysis." Qualitative Health Research. 15(9): 1277-1288.

Hunt, Scott. 2011. "State Halts Liquid Cremation." The Columbus Dispatch. Retrieved from https://www.dispatch.com/article/20110323/NEWS/303239720

Kastenbaum, Robert and Christopher M. Moreman. 2018. Death, Society, and Human Experience. $12^{\text {th }}$ ed. New York: Routledge.

Kelly, Suzanne. 2015. Greening Death: Reclaiming Burial Practices and Restoring our Tie to the Earth. New York: Rowman and Littlefield Publishers.

Kiley, Brendan. 2019. "Washington Becomes First State to Legalize Human Composting." The Seattle Times. Retrieved from https://www.seattletimes.com/ seattle-news/washington-becomes-first-state-to-legalize-human-composting/

Knight, Frances. 2018. "Cremation and Christianity: English Anglican and Roman Catholic Attitudes to Cremation Since 1885." Morality. 23(4): 301-319.

Kopp, Steven W. and Elyria Kemp. 2007. "The Death Care Industry: A Review of Regulatory and Consumer Issues." The Journal of Consumer Affairs. 41(1): 150173.

Laderman, Gary. 1996. The Sacred Remains: American Attitudes toward Death, 17991883. New Haven: Yale University Press.

Laderman, Gary. 2003. Rest in Peace: A Cultural History of Death and the Funeral Home in Twentieth-Century America. Oxford: Oxford University Press.

LaFleur, William. 1992. Liquid Life: Abortion and Buddhism in Japan. Princeton: Princeton University Press.

Lasnoski, Kent J. 2016. “Are Cremation and Alkaline Hydrolysis Morally Distinct?” The National Catholic Bioethics Quarterly. 16(2): 233-242.

Laylin, Tafline. 2018. "Washington Could Become the First State to Legalize Human Composting." NBC News. Retrieved from https://www.nbcnews.com/news/usnews/washington-could-become-first-state-legalize-human-composting-n952421

Lewis, Joanne M., Michelle DiGiacomo, David C. Currow, and Patricia M. Davidson. 
2011. "Dying in the Margins: Understanding Palliative Care and Socioeconomic Deprivation in the Developed World." Journal of Pain and Symptom Management. 42(1): 105-118.

Long, Charles H. 1986. Significations: Signs, Symbols, and Images in the Interpretation of Religion. Philadelphia: Fortress Press.

Lowrie, Daniel, Robin Ray, David Plummer, and Matthew Yau. 2018. "Exploring the Contemporary Stage and Scripts for the Enactment of Dying Roles: A Narrative Review of the Literature." OMEGA - Journal of Death and Dying. 76(4): 328350.

MacDougall, Katelyn. 2020. "What is Death Planning?” Cake Blog. Retrieved from https://www.joincake.com/blog/what-is-death-planning/

MacMurray, Nick and Robert Futrell. 2019. "Ecological Death Reform and Death System Change." OMEGA - Journal of Death and Dying. 0(0): 1-25.

McIlwain, Charlton D. 2003. Death in Black and White: Death, Ritual, and Family Ecology. Cresskill, NJ: Hampton Press, Inc.

Mellor, Phillip A. 1992. "Death in High Modernity: The Contemporary Presence and Absence of Death." The Sociological Review. 40(1): 11-30.

Mellor, Philip A. and Chris Shilling 1993. "Modernity, Self-Identity, and the Sequestration of Death.” Sociology. 27(3): 411-431.

Miller, Jennifer. 2020. "Boom Time for Death Planning.” The New York Times. Retrieved from https://www.nytimes.com/2020/07/16/business/boom-time-for-deathplanning.html

Mims, Cedric. 2000. When We Die: The Science, Culture, and Rituals of Death. New York: St. Martin's Press.

Mirkes, Sr. Renée. 2008. "The Mortuary Science of Alkaline Hydrolysis: Is It Ethical?" The National Catholic Bioethics Quarterly. 8(4): 683-695.

Missouri Catholic Conference. 2018. "Missouri Catholic Bishops Oppose Use of Alkaline Hydrolysis." The Catholic Missourian. Retrieved from https://catholicmissourianonline.com/stories/missouri-catholic-bishops-opposeuse-of-alkaline-hydrolysis, 1095

Mitford, Jessica. 1963. The American Way of Death. New York: Simon \& Schuster.

Mitford, Jessica. 1998. The American Way of Death Revisited. New York: Alfred A. 
Knopf, Inc.

Moodie, Susanna. 1989. Life in the Clearings versus the Bushes. Toronto: New Canadian Library.

My Wonderful Life. 2016. Minneapolis: Kruskopf \& Company. Retrieved August 15, 2019. Retrieved from https://www.mywonderfullife.com.

NAE. 2009. "Evangelical Leaders Prefer Traditional Burial." National Association of Evangelicals. Retrieved from https://www.nae.net/evangelical-leaders-prefertraditional-burial/

NFDA. 2015. "2015 NFDA Cremation and Burial Report: Research, Statistics, and Projections." National Funeral Directors Association. Retrieved from https://iogr.memberclicks.net/assets/docs/2015\%20nfda\%20cremation\%20and\%2 Oburial\%20report.pdf

NFDA. 2019. "Consumers Moving Past Tradition For Funerals, Survey Says.” National Funeral Directors Association. Retrieved from https://nfda.org/news/mediacenter/nfda-news-releases/id/4703/consumers-moving-past-tradition-for-funeralssurvey-says

NFDA. 2021. "Statistics." National Funeral Directors Association. Retrieve from https://nfda.org/news/statistics

Olson, Phillip R. 2014. "Flush and Bone: Funeralizing Alkaline Hydrolysis in the United States." Science, Technology, \& Human Values. 39(5): 666-693.

Olson, Phillip R. 2016. "Custody of the Corpse: Controlling Alkaline Hydrolysis in US Death Care Markets." In Death in a Consumer Culture. Susan Dobscha (ed). New York: Routledge.

Orpett Long, Susan and Sonja Salome Buehring. 2017. "Remember the Dead: Agency, Authority, and Mortuary Practices in Interreligious Families in the United States." In Death in the Early $21^{\text {st }}$ Century: Authority, Innovation, and Mortuary Rites. Sébastien Penmellen Boret, Susan Orpett Long and Sergei Kan (eds). New York: Palgrave MacMillan.

Osborne, Thomas. 1997. "Of Health and Statecraft." In Foucault: Health and Medicine. Alan Petersen and Robin Burton (eds). New York: Routledge.

Palánová, Klára Frolíková, Jan Kovář, Tomáš Babor, Ivona Dlábiková, and Ondřej Juračka. 2015. "Requirements for Cremation Architecture in Contemporary Secularized Society." Ricerche e progetti per il territorio, la città e l'architettura. 8: $150-158$. 
Pals, Daniel L. 2006. Eight Theories of Religion. $2^{\text {nd }}$ ed. New York: Oxford University Press.

Park, Chris C. 1994. Sacred Worlds: An Introduction to Geography and Religion. New York: Routledge.

PCCC. 2021. "Learn About Green Burial.” Prairie Creek Conservation Cemetery. Retrieved from https://www.prairiecreekconservationcemetery.org/faq-greenburial

Petersen, Alan. 1997. "Risk, Governance and the New Public Health." In Foucault: Health and Medicine. Alan Petersen and Robin Bunton (eds). New York: Routledge

Pollock, Kristian and Jane Seymour. 2018. "Reappraising the 'Good Death' for Populations in the Age of Ageing." Age and Ageing. 0: 1-3.

Powell, Devin. 2017. "Dissolve the Dead? Controversy Swirls around Liquid Cremation." Scientific American. Retrieved from https://www.scientificamerican.com/article/dissolve-the-dead-controversy-swirlsaround-liquid-cremation/

Powell, Mark, Jenny Hockey, Trish Green, and Andy Clayden. 2011. "'I Bury Boxes, not Bodies': Identity, Emotionality and Natural Burial.” ASA Online. 1(3): 1-18.

Prothero, Stephen. 2001. Purified by Fire: A History of Cremation in America. Berkeley: University of California Press.

Rani, Smitha. 2020. "A Review of the Management and Safe Handling of Bodies in Cases Involving COVID-19." Medicine, Science, and the Law. 60(4): 287-293.

Ray Lambert, Hannah. 2021. "Oregon Could Become Second State to Allow Human Composting." Retrieved from https://www.koin.com/news/oregon/oregon-couldbecome-second-state-to-allow-human-composting/

Rappaport, Roy. 1999. Ritual and Religion in the Making of Humanity. New York: Cambridge University Press.

Read, Jason. 2009. "A Genealogy of Homo-Economicus: Neoliberalism and the Production of Subjectivity." Foucault Studies. 6: 25-36.

Rebay-Salisbury, Katherina. 2012. "Inhumation and Cremation: How Burial Practices are Linked to Beliefs.” In Embodied Knowledge: Historical Perspectives on Belief and Technology. Marie Louise Stig Sørensen and Katharina Rebay-Salisbury (eds). Barnsley, UK: Oxbow Books. 
Robinson, Georgina M. 2021. "Dying to Go Green: The Introduction of Resomation in the United Kingdom." Religions. 12: 1-22.

Robson, David. 2016. "The Women Who Forced Us to Look Death in the Face." Retrieved from https://www.bbc.com/future/article/20160721-how-jessica-mitford-changedour-ideas-about-death

Rosen, Fred. 2004. Cremation in America. Amherst, NY: Prometheus Books.

Ruck, Agnieszka. 2019. "Catholic Officials: State's Green Burial Laws Might not Respect Bodies." Catholic News Service. Retrieved from https://cruxnow.com/church-in-the-usa/2019/08/catholic-officials-states-greenburial-laws-might-not-respect-bodies/

Ruderman, Alicia. 2021. "The Benefits of Having an End of Life Planning Worksheet." Lantern. Retrieved from https://lantern.co/articles/benefits-of-an-end-of-lifeplanning-worksheet

Rumble, Hannah, John Troyer, and Tony Walter. 2014. "Disposal or Dispersal? Environmentalism and Final Treatment of the British Dead." Mortality. 19(3): 243-260.

Seale, Clive. 1998. Constructing Death: The Sociology of Death, Dying, and Bereavement. Cambridge, UK: Cambridge University Press.

Selby, Daniele. 2020. "Why You Should Plan Ahead After Big Life Events." Lantern. Retrieved from https://lantern.co/articles/why-its-important-to-plan-ahead-afterbig-life-events

Seligman, Adam B., Robert P. Weller, Michael J. Puett, and Bennett Simon. 2008. Ritual and Its Consequences: An Essay on the Limits of Sincerity. Oxford: Oxford University Press.

Slocum, Joshua and Lisa Carlson. 2011. Final Rights: Reclaiming the American Way of Death. Hinesburg, VT: Upper Access, Inc., Book Publishers.

Smith, Alexander, Ellen McCarthy, Mary E. Paulk, and Tracy Balboni. 2009. "Racial and Ethnic Differences in Advance Care Planning Among Patients With Cancer: Impact of Terminal Illness Acknowledgment, Religiousness, and Treatment Preferences." Journal of Clinical Oncology. 26(25): 4131-4137.

Smith, George Davey, Douglas Carroll, Sandra Rankin, and David Rowan. 1992. 
"Socioeconomic Differentials in Mortality: Evidence from Glasgow Graveyards." BMJ: British Medical Journal. 305(6868): 1554-1557.

Smith, Jonathan Z. 1982. Imagining Religion: From Babylon to Jonestown. Chicago: University of Chicago Press.

Smith, Alexander K. and Vyjeyanthi S. Periyakoil. 2018. "Should we Bury the 'Good Death'?" Journal of the American Geriatrics Society. 566: 856-858.

Solomon, Adina. 2020. "More States Legalize Dissolving Bodies in Water." U.S. News \& World Report. Retrieved from https://www.usnews.com/news/beststates/articles/2020-03-12/more-states-legalize-alkaline-hydrolysis-dissolvingdead-bodies-in-water

Stock, Paul V. and Mary Kate Dennis. 2021. "Up in Smoke or Down with Worms? Older Adult Environmentalist Discourse on Disposal, Dispersal, and (Green) Burial." Mortality. 1-17.

Stowe Jr., Johnny P., Elise Vernon Schmidt, and Deborah Green. 2001. "Toxic Burials: The Final Insult.” Conservation Biology. 15(6): 1817-1819.

Tavares de Cruz, Nicholas Joseph, Álvaro Guillermo Rojas Lezana, Paulo da Cruz Freire dos Santos, Ibsen Mateus Bittencourt Santana Pinto, Claudio Zancan, and Gustavo Henrique Silva de Souza. 2017. "Environmental Impacts Caused by Cemeteries and Crematoria, New Funeral Technologies, and Preferences of the Northeastern and Southern Brazilian Population as for the Funeral Process." Environmental Science and Pollution Research. 24: 24121-24134.

Thursby, Jaqueline S. 2006. Funeral Festivals in America: Rituals for the Living. Lexington: The University Press of Kentucky.

Turner, Victor. 1969. The Ritual Process: Structure and Anti-Structure. New Brunswick: Aldine Transaction.

USCCB. 2019. Catechism of the Catholic Church (2 ${ }^{\text {nd }}$ ed). Washington, D.C.: United States Catholic Conference of Bishops.

Van Gennep, Arnold. 1960. Rites of Passage. Chicago: University of Chicago Press.

Vasquez, Manuel A. and Marie Friedmann Marquardt. 2003. Globalizing the Sacred: Religion Across the Americas. New Brunswick: Rutgers University Press.

Walter, Tony. 1994. The Revival of Death. New York: Routledge.

Walter, Tony. 2017. "Promote, Oppose, Accommodate or Compensate? Four Ways 
Religion Can Interact with Society's Death Practices.” Bereavement Care. 36(1): 19-24.

Washington, Harriet A. 2008. Medical Apartheid: The Dark History of Medical Experimentation on Black Americans from Colonial Times to the Present. New York: Anchor.

Wasik, John F. 2014. "Lifting from Others the Burden of your Own Death." New York Times. Retrieved from https://www.nytimes.com/2014/05/15/business/ retirementspecial/proper-death-planning-is-a-final-gift-to-loved-ones.html?_r=0

WHO. 2020. Interim Guidance: Infection Prevention and Control for the Safe Management of a Dead Body in the Context of COVID-19. World Health Organization.

Worpole, Ken. 2003. Last Landscapes: The Architecture of the Cemetery in the West. London: Reaktion Press.

Wynn, Kelli. 2013. "Controversial Liquid Cremation Sought in Ohio.” Dayton Daily News. Retrieved from https://www.daytondailynews.com/news/local/ controversial-liquid-cremation-sought-ohio/qCV1mPXI9ytY3Z7fctalZM/ 


\section{VITA}

Douglas Valentine was born in Peoria, IL on December 11, 1984. He attended elementary and high school in East Peoria, IL, where he graduated in 2003. After spending two years at Illinois Central College, he transferred to Bradley University, graduating summa cum laude in 2008. He earned his Master of Arts degree in Religious Studies from the University of Missouri-Columbia in 2012. After teaching and administering at Central Methodist University from 2012-2014, he reenrolled at the University of MissouriColumbia to pursue his doctorate in Sociology, as well as minors in Women's \& Gender Studies and College Teaching, and a graduate certificate in Higher Education Administration. He and his wife, Chandra, have two sons, Hollis and Simon. 